\title{
Trends in Ozonation Disinfection By-Products- Occurrence, Analysis and Toxicity of Carboxylic Acids
}

\author{
Rama Pulicharla ${ }^{1}$, François Proulx ${ }^{1}$, Sonja Behmel ${ }^{2}$, Jean-B. Sérodes ${ }^{3}$ and \\ Manuel J. Rodriguez ${ }^{1, *}$ \\ 1 École Supérieure D’aménagement du Territoire et de Développement Régional, Pavillon \\ Félix-Antoine-Savard, bureau 1616, 2325, rue des Bibliothèques, Université Laval, Québec, QC G1V 0A6, \\ Canada; rama.pulicharla.1@ulaval.ca (R.P.); Francois.Proulx@esad.ulaval.ca (F.P.) \\ 2 AGIRO, 433 Delage, Québec, QC G3G 1H4, Canada; sonja.behmel@agiro.org \\ 3 Département de Génie Civil et Génie des Eaux, Pavillon Pouliot, Université Laval, Québec, QC G1V 0A6, \\ Canada; jean-baptiste.serodes.1@ulaval.ca \\ * Correspondence: manuel.rodriguez@esad.ulaval.ca; Tel.: +418-656-2131 (ext. 408933)
}

Received: 13 February 2020; Accepted: 29 February 2020; Published: 9 March 2020

\begin{abstract}
Ozonation is becoming a common disinfection method for drinking water treatment. This has prompted the investigation of ozonation disinfection by-products (ODBPs) in drinking water. Ozonation generates a diverse range of carbonyl disinfection by-products, including carboxylic acids, aldehydes, ketones and aldo-ketoacids. Among these ODBPs, carboxylic acid by-products (CABPs) are observed in higher concentrations compared to other carbonyl by-products. However, relatively little research has been conducted on CABPs, including their precursors, formation and occurrence, methods of detection and toxicity. This review outlines the occurrence and variability of CABPs in a number of water sources treated and disinfected with ozonation. It considers the effect of ozonation parameters, including ozone dose, temperature and time of ozonation on the formation of CABPs. The review also discusses the various analytical approaches for CABP quantification, as well as their possible toxicity in drinking water.
\end{abstract}

Keywords: Carboxylic acid by-products; Drinking water; Analysis; Toxicity; Ozonation

\section{Introduction}

Chlorine is the most widely used and studied disinfectant in water treatment plants (WTPs) [1]. However, the discovery of chlorination disinfection by-products (DBPs) such as halogenated DBPs (trihalomethanes (THMs) and haloacetic acids (HAAs)) has led to a revolutionary change in water disinfection practices due to their potential disease-causing effects [2,3]. To balance disinfection (risks of microbial contamination) and the potential health impacts of DBPs in drinking water, many countries such as Canada, USA, Japan, European countries (Netherlands and Sweden), South Africa, New Zealand and the United Kingdom, as well the World Health Organization (WHO), have imposed maximum limits for THM and HAA concentrations. As well as, alternative and advanced disinfectants such as ozone, chloramines, chlorine dioxide and ultraviolet radiation have been evaluated to meet the regulatory requirements of THMs and HAAs [4,5]. Among these disinfectants, ozonation has been emerging as an efficient disinfection method.

Water disinfection using ozonation was first introduced in France in 1886 [6]. Ozone is a versatile and valuable disinfectant due to its powerful oxidizing capacity, its ability to be applied at different stages throughout the treatment plant. Many WTPs have started to utilize ozone disinfection in order to tackle the halogenated DBPs that are formed by disinfection with chlorine. A recent review by Loeb et al. [7] predicted a $0.6 \%$ to $34.9 \%$ growth in ozonation facilities across the world by 2016 . Only a 
few studies have been conducted to identify, quantify and measure the toxicity of ozonation DBPs (ODBPs) compared to chlorination DBPs. The reported ODBPs can be divided into two main categories: (1) inorganic ODBPs, whose formation relies mainly on the bromide levels in raw water; and (2) organic ODBPs, whose formation mainly relies on the characteristics of natural organic matter (NOM), ozone dose and contact time. A multitude of organic ODBP types have been reported, including aldehydes, ketones, carboxylic acids, hydroxy acids, alcohols, esters, ketoaldehydes, aldo acids, keto acids and alkanes $[8,9]$. Limited toxicity data are available for these organic ODBPs, which puts into question the safety of ozonated water [10].

Organic ODBPs have been classified into three major classes: aldehydes, ketones and carboxylic acids (CAs; including aldo-acid and keto-acid DBPs). The majority of studies have been focused on aldehyde and ketone ODBPs due to their easy extraction and toxic nature [10,11]. Extracting CAs is challenging due to their high solubility. Regardless, limited data is available concerning the effects of CA by-products (CABPs) on living organisms. Screening for ODBPs has revealed relatively higher levels of CABPs in ozonated water compared to other classes of ODBPs in WTPs [12]. Higher levels of CABPs have been shown to form with higher ozone doses [13] and water treatment processes are less effective at removing CABPs in comparison to other classes of ODBPs [8].

This review investigates the current levels of CABPs in drinking water, as a result of ozonation. We discuss the effects of various parameters on the formation of CABPs, such as temperature, NOM concentration and composition, ozone dose and contact time. We also review details about the analytical advancements for quantifying CABPs. This review also addresses the removal of CABPs in water treatment plants and the challenges in evaluating their toxicity.

\section{Precursors of CABPs}

Organic matter $(\mathrm{OM})$ in water sources is the main precursor for the formation of DBPs [14]. The primary sources of $\mathrm{OM}$ are the metabolic processes of phytoplankton and zooplankton and also human activities such as agricultural and forestry (pesticides and fertilizers), industrial (processing effluents, waste disposal sites) and technological (municipal landfill, mining, construction and transport) activities. These numerous sources contribute the complexity of $\mathrm{OM}$, due to the daily, regional and global variations associated with each activity. It is therefore very difficult to accurately characterize OM. In general, natural organic matter (NOM) is divided into humic substances (hydrophobic humic acids (HAs) and hydrophilic fulvic acids (FAs)) and humins, based on its solubility. HAs are only soluble at a $\mathrm{pH}$ above 2, FAs are soluble at all $\mathrm{pH}$ values and humins are insoluble at all $\mathrm{pH}$ values [15]. The composition of humic substances differs depending on the source water, such as surface water (rivers, lakes or watersheds), wastewater or groundwater with varying types of human activity. Because of this structural and compositional complexity, the mechanism of DBP's generation from OM remains uncertain $[16,17]$.

In case of Ozonation, ozone and hydroxide radicals (formed by ozone decomposition) can oxidize NOM to form readily biodegradable ODBPs [18]. The quantity and type of ODBPs formed are highly unpredictable. Various factors, in particular the composition and the concentration of NOM, disinfection conditions (ozone dose, contact time) and other treatment processes in WTPs largely control the formation of ODBPs. As presented in Figure 1, different types and amounts of ODBPs have been reported, including CABPs, aldo- and keto- acids and aldehydes [19]. More than $60 \%$ of organic matter was unidentified during ozonation disinfection. Among the identified organic matter $(40 \%)$, 26-33\% belong to CABPs [20]. According to experimental research by Krasner et al. (1996), 67\% of CABPs were removed by water treatment processes, whereas other classes of ODBPs were removed $>80-85 \%[19,21]$. The higher levels of formation and lower levels of CABP removal in WTPs have generated additional interest in CABPs research.

To identify the precursors of CABPs, studies have used NOM extracted from water sources, such as surface water and groundwater or commercial humic substances, for ozonation. Xie and Reckhow [22] isolated and purified fulvic acids (DOC: $4 \mathrm{mg} / \mathrm{L}$ ) from the Thousand Acre Reservoir in the USA. The ozonation of isolated fulvic acid led to the formation of ketoacids (CABPs; glyoxylic 
acid, pyruvic acid, and ketomalonic acid). Additionally, the concentration of ketoacids increased with the ozone dose (0-3 mg/L). Griffini et al. [23] observed a similar increase in these CABPs along with increased ozone doses, using water from Arno River for their experiments. These studies concluded that the fulvic acids from NOM might be responsible for the formation of ketoacid CABPs upon ozonation. However, these studies did not mention the actual mechanism or pathways for ketoacid formation. On the other hand, ozonating the hydrophobic extract of NOM (humic acids) has generated higher levels of aldehydes than hydrophilic NOM (fulvic acids). A large number of studies have reported that aldehydes also act as significant precursors of CABPs formation [24-26]. A recent study by Li et al. [14] has highlighted the equal importance of hydrophilic and hydrophobic NOM in the formation of ODBPs such as acids, aldehydes and hydrocarbons during ozonation. Therefore, despite the fact that current studies could not confirm the specific precursors or mechanisms for the formation of CABPs, they do emphasize that CABPs are a common DBPs formed by the ozonation of NOM.

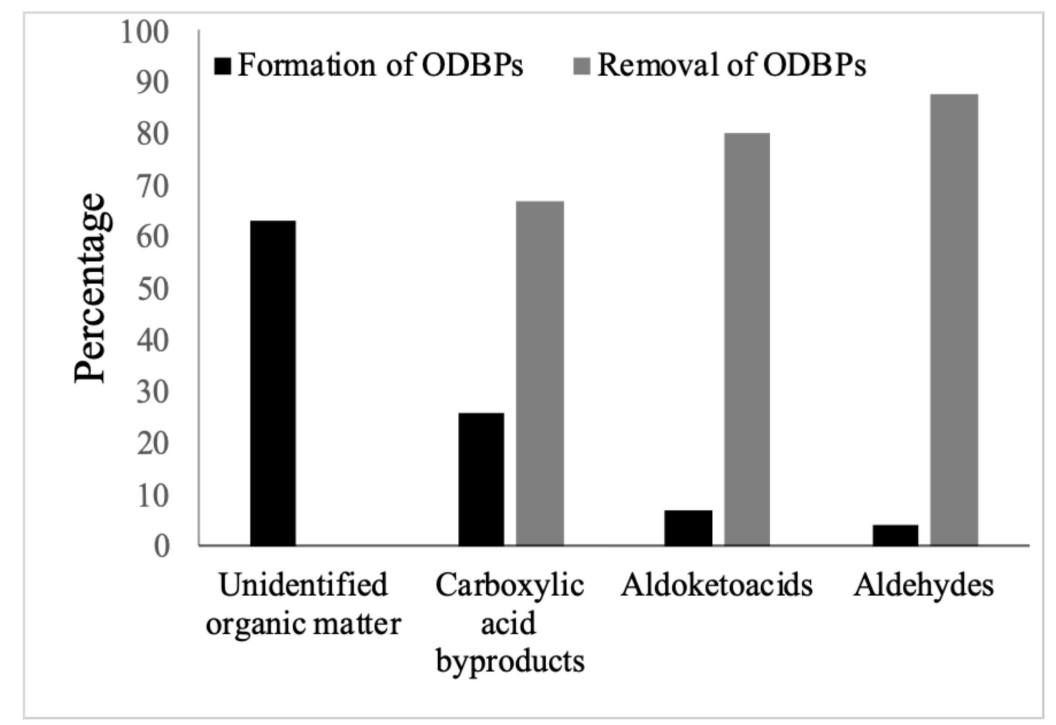

Figure 1. Percentage of formation and removal of disinfection by-products identified during ozonation in drinking water samples [19].

Based on what is currently known, it is not yet possible to definitively identify the precursors of CABPs since both fulvic acid (itself a precursor) as well as the oxidized BPs of humic acid (aldehydes) can act as $C A B P$ precursors. In addition to the humic substances, $C A B P s$ can also be formed by the direct oxidation of aldehydes that are present in raw water. Therefore, the generation of CABPs is typically influenced by the characteristics of NOM, such as its concentration and structural composition $[27,28]$.

\section{Formation and occurrence of CABPs in Drinking Water}

CABPs have a carboxylic acid functional group, which can undergo further oxidation to form carbon dioxide and water. In general, the process of CABP formation by oxidation takes place as follows: alcohol $(-\mathrm{OH}) \rightarrow$ ketone $(-\mathrm{C}=\mathrm{O}) \rightarrow$ aldehyde $(-\mathrm{HC}=\mathrm{O}) \rightarrow$ ester $(-\mathrm{COOR}) \rightarrow$ carboxylic acid $(-\mathrm{COOH})$. Many studies have confirmed the formation and have measured the concentration of aldehyde byproducts upon ozonation but few studies have reported the presence of CABPs along with aldehydes. Among the reported CABPs, some were identified in full-scale studies while others were identified in pilot-scale and bench-scale experiments where extracted NOM or humic substances were ozonated. Table 1 presents the current levels of CABPs that have been detected before and after ozonation of surface water. The sum of the quantified CAs has been calculated and presented in the Table 1 to compare the levels of CABPs before and after ozonation. Most of the studies showed that the sum of CABPs concentrations increased after ozonation. 
Table 1. Levels of carboxylic acid by-products (CABPs) reported in ozonated drinking water samples across the world.

\begin{tabular}{|c|c|c|c|c|c|c|c|}
\hline \multirow[b]{2}{*}{ Location } & & \multirow[b]{2}{*}{$\begin{array}{l}\text { Ozonation Conditions and } \\
\text { Water Characteristics }\end{array}$} & \multirow[b]{2}{*}{ Carboxylic Acids (CAs) } & \multirow[b]{2}{*}{$\begin{array}{l}\text { Experiment } \\
\text { Type }\end{array}$} & \multicolumn{2}{|c|}{ Estimated Concentrations of CAs } & \multirow[b]{2}{*}{ Ref. } \\
\hline & & & & & $\begin{array}{l}\text { Raw Water (Total: } \\
\text { Minimum to } \\
\text { Maximum) }\end{array}$ & $\begin{array}{l}\text { Ozonated Water } \\
\text { (Total: Minimum to } \\
\text { Maximum) }\end{array}$ & \\
\hline 1 & $\begin{array}{l}\text { Los Angeles Aqueduct } \\
\text { filtration plant, } \\
\text { California, US }\end{array}$ & $\begin{array}{l}\text { Ozone dose: } 1 \mathrm{mg} / \mathrm{L} ; \mathrm{TOC}: \\
1.1-1.9 \mathrm{mg} / \mathrm{L} ; \text { total alkalinity: } \\
113-123 \mathrm{mg} / \mathrm{L} \text { as } \mathrm{CaCO}_{3}\end{array}$ & $\begin{array}{l}\text { Hexanoic acid, heptanoic acid, benoic acid, octanoic } \\
\text { acid, nonanoic acid, decanoic acid, undecanoic acid, } \\
\text { dodecanoic acid, tridecanoic acid, pentadecanoic acid, } \\
\text { tetradecanoic acid, 9-hexadecenoic acid, hexadecenoic } \\
\text { acid, heptadecanoic acid, octadecanoic acid, } \\
\text { nonadecanoic acid, eicosanoic acid, Heneicosanoic acid, } \\
\text { docosanoic acid, tricosanoic acid, tetracosanoic acid }\end{array}$ & Full scale & $\begin{array}{l}32-3975 \mathrm{ng} / \mathrm{L} \\
(12482 \mathrm{ng} / \mathrm{L})\end{array}$ & $\begin{array}{l}20-1705 \mathrm{ng} / \mathrm{L} \\
(6954 \mathrm{ng} / \mathrm{L})\end{array}$ & [29] \\
\hline 2 & $\begin{array}{l}\text { Los Angeles Aqueduct } \\
\text { Water (LAAW), } \\
\text { California, US }\end{array}$ & $\begin{array}{l}\text { Ozone dose: } 0.22 \mathrm{mg} \\
\text { ozone/L-min; flow rate: } \\
1.0 \mathrm{~L} / \mathrm{min} \text {;OC: } 1.6 \mathrm{mg} / \mathrm{L} \text {; } \\
\text { alkalinity- } 120 \mathrm{mg} \text { as } \\
\mathrm{CaCO}_{3} / \mathrm{L} \text {. }\end{array}$ & $\begin{array}{l}\text { Hexanoic acid, heptanoic acid, benoic acid, octanoic } \\
\text { acid, nonanoic acid, decanoic acid, undecanoic acid, } \\
\text { dodecanoic acid, tridecanoic acid, pentadecanoic acid, } \\
\text { tetradecanoic acid, 9-hexadecenoic acid, hexadecenoic } \\
\text { acid, heptadecanoic acid, octadecanoic acid, } \\
\text { nonadecanoic acid, eicosanoic acid, Heneicosanoic acid, } \\
\text { docosanoic acid, tricosanoic acid, tetracosanoic acid }\end{array}$ & Batch scale & $\begin{array}{l}0.9-793 \mathrm{ng} / \mathrm{L} \\
(2498.7 \mathrm{ng} / \mathrm{L})\end{array}$ & $\begin{array}{l}21-341 \mathrm{ng} / \mathrm{L} \\
(1111 \mathrm{ng} / \mathrm{L})\end{array}$ & [29] \\
\hline 3 & $\begin{array}{l}\text { State Project Water } \\
\text { (SPW), California, US }\end{array}$ & $\begin{array}{l}\text { Ozone dose: } 0.22 \mathrm{mg} \\
\text { ozone/L-min; flow rate: } 1.0 \\
\mathrm{~L} / \mathrm{min} \text {; TOC: } 2.6 \mathrm{mg} / \mathrm{L} ; \\
\text { alkalinity- } 84-88 \text { as } \mathrm{CaCO}_{3} / \mathrm{L} \text {. }\end{array}$ & $\begin{array}{l}\text { Heptanoic acid, decanoic acid, dodecanoic acid, } \\
\text { tridecanoic acid, tetradecanoic acid, pentadecanoic acid, } \\
\text { 9-hexadecenoic acid, hexadecenoic acid, heptadecanoic } \\
\text { acid, octadecanoic acid }\end{array}$ & Batch scale & $\begin{array}{l}75-1900 \mathrm{ng} / \mathrm{L} \\
(4855 \mathrm{ng} / \mathrm{L})\end{array}$ & $\begin{array}{l}46-1600 \mathrm{ng} / \mathrm{L} \\
(4448) \mathrm{ng} / \mathrm{L}\end{array}$ & \\
\hline 4 & $\begin{array}{l}\text { Anconella plant in } \\
\text { Florence (Arno River } \\
\text { water), Italy }\end{array}$ & $\begin{array}{l}0.7-1.6 \mathrm{mgO}_{3} / \mathrm{mgC} ; \mathrm{DOC}: \\
0.73-2.39 \mathrm{mg} / \mathrm{L} ; \text { alkalinity: } \\
148-235 \mathrm{mg} / \mathrm{L} \text { as } \mathrm{HCO}_{3} \text {. }\end{array}$ & $\begin{array}{l}\text { Glyoxylic acid, pyruvic } \\
\text { acid, keto malonic acid }\end{array}$ & Batch scale & No data & $20-112 \mu \mathrm{g} / \mathrm{L}$ & [23] \\
\hline \multirow[t]{2}{*}{5} & \multirow[t]{2}{*}{$\begin{array}{l}\text { Britannia Water } \\
\text { Purification Facility, } \\
\text { Ottawa, Ontario, } \\
\text { Canada }\end{array}$} & $\begin{array}{l}\text { Summer water matrix; TOC: } \\
3.7 \mathrm{mg} / \mathrm{L} \text {; ozone dose: } \\
0.1-0.5 \mathrm{mg} / \mathrm{min} \text {; alkalinity: } 9.2 \\
\text { as } \mathrm{CaCO}_{3} / \mathrm{L} \text {; pH: 6; } \\
\text { experimental temperature: } 22 \\
{ }^{\circ} \mathrm{C} \text {. }\end{array}$ & \multirow[t]{2}{*}{ Formic acid, acetic acid, glycolic acid, pyruvic acid } & \multirow[t]{2}{*}{ Full scale } & No data & $\begin{array}{l}659.8-873 \\
(1102) \mu \mathrm{g} / \mathrm{L}\end{array}$ & \multirow[t]{2}{*}{ [30] } \\
\hline & & $\begin{array}{l}\text { Fall water matrix; TOC: } 2.8 \\
\mathrm{mg} / \mathrm{L} ; \text { ozone dose: } 0.1-0.5 \\
\mathrm{mg} / \mathrm{min} \text {; alkalinity: } 10 \text { as } \\
\mathrm{CaCO}_{3} / \mathrm{L} \text {; } \mathrm{pH}: 6 \text {; experimental } \\
\text { temperature: } 11^{\circ} \mathrm{C} \text {. }\end{array}$ & & & No data & $\begin{array}{l}196.5-244.8 \\
(327) \mu \mathrm{g} / \mathrm{L}\end{array}$ & \\
\hline
\end{tabular}


Table 1. Cont

\begin{tabular}{|c|c|c|c|c|c|c|c|}
\hline \multirow[b]{2}{*}{ Location } & & \multirow[b]{2}{*}{$\begin{array}{l}\text { Ozonation Conditions and } \\
\text { Water Characteristics }\end{array}$} & \multirow[b]{2}{*}{ Carboxylic Acids (CAs) } & \multirow[b]{2}{*}{$\begin{array}{l}\text { Experiment } \\
\text { Type }\end{array}$} & \multicolumn{2}{|c|}{ Estimated Concentrations of CAs } & \multirow[b]{2}{*}{ Ref. } \\
\hline & & & & & $\begin{array}{l}\text { Raw Water (Total: } \\
\text { Minimum to } \\
\text { Maximum) }\end{array}$ & $\begin{array}{l}\text { Ozonated Water } \\
\text { (Total: Minimum to } \\
\text { Maximum) }\end{array}$ & \\
\hline 6 & $\begin{array}{l}\text { Water treatment plant, } \\
\text { Ontario, Canada }\end{array}$ & No data & $\begin{array}{l}\text { Acetic acid, glycolic acid, butyric acid, formic acid, } \\
\text { ketobutyric acid, pyruvic acid }\end{array}$ & Full scale & No data & $1-277$ g/L (522) & [31] \\
\hline 7 & $\begin{array}{l}\text { California state project } \\
\text { water }\end{array}$ & $\begin{array}{l}\text { Ozone dose: } 1.6 \mathrm{mg} / \mathrm{L} \text {; } \\
\text { pH: } 8.3 .\end{array}$ & $\begin{array}{l}\text { Acetic acid, propionic acid, formic acid, pyruvic acid, } \\
\text { glyoxylic acid, oxalic acid and ketomalonic acid. }\end{array}$ & Full scale & No data & $3.7-210.3 \mu \mathrm{g} / \mathrm{L}$ & [32] \\
\hline 8 & $\begin{array}{l}\text { The Mannheim Water } \\
\text { Treatment Plant in } \\
\text { Kitchener, Ontario, } \\
\text { Canada }\end{array}$ & $\begin{array}{l}\text { Ozone dose: } 1.8-4 \mathrm{mg} / \mathrm{L} \text {; } \\
\text { organic carbon: } 4-6.3 \mathrm{mg} / \mathrm{L} \\
\text { temperature: } 2.8-22^{\circ} \mathrm{C} \text {; } \\
\text { alkalinity: } 140-320 \mathrm{mg} / \mathrm{L} \text { as } \\
\mathrm{CaCO}_{3} \text {. }\end{array}$ & $\begin{array}{l}\text { Acetic acid, glycolic acid, formic acid, butyric acid, } \\
\text { pyruvic acid, } \\
\alpha \text {-ketobutyric acid }\end{array}$ & Full scale & $\begin{array}{l}\text { Less than detection } \\
\text { limits }\end{array}$ & $18-271 \mu \mathrm{g} / \mathrm{L}$ & [33] \\
\hline 9 & $\begin{array}{l}\text { Valdosta Water } \\
\text { Treatment Plant, } \\
\text { Valdosta, GA (Treats } \\
\text { ground water) }\end{array}$ & $\begin{array}{l}\text { TOC: } 1.0 \mathrm{mg} / \mathrm{L} \text {; Ozone dose: } \\
3.0 \mathrm{mg} / \mathrm{L} \text {; contact time: } 90 \mathrm{sec} \text {. }\end{array}$ & Glyoxylic acid, pyruvic acid & Batch scale & No data & Identified & [34] \\
\hline 10 & $\begin{array}{l}\text { Lanier Water } \\
\text { Treatment Plant, } \\
\text { Gwinnett County }\end{array}$ & $\begin{array}{l}\text { TOC: } 1.2 \mathrm{mg} / \mathrm{L} \text {; Ozone diose: } \\
0.5 \mathrm{mg} / \mathrm{L} \text {; contact time: } 4 \mathrm{~min} .\end{array}$ & $\begin{array}{l}\text { Glyoxylic acid, pyruvic acid, ketomanoic acid } \\
\text { Oxaloacetic acid }\end{array}$ & Full scale & No data & Identified & \\
\hline 11 & $\begin{array}{l}\text { Poznań Water } \\
\text { Treatment and Sewage } \\
\text { Co. }\end{array}$ & $\begin{array}{l}\text { TOC: } 3.8-6.5 \mathrm{mg} / \mathrm{L} ; \mathrm{pH}: \\
\text { 7.06-7.48; alkalinity: } \\
\text {-3.35-4.30 mval/L; ozone } \\
\text { dose: } 40-60 \mathrm{mg} / \mathrm{L} \text {. }\end{array}$ & Formic and oxalic acid & Full scale & No data & $1-480 \mu \mathrm{g} / \mathrm{L}$ & [35] \\
\hline 12 & $\begin{array}{l}\text { Feng-San Reservoir, } \\
\text { Taiwan }\end{array}$ & $\begin{array}{l}\text { DOC: } 3.0-3.5 \mathrm{mg} / \mathrm{l} \text {; ozone } \\
\text { dose: } 0.5-11 \mathrm{mg} / \mathrm{mg} \text { DOC }\end{array}$ & $\begin{array}{l}\text { Propanoic acid, Benzoic acid, Octanoic acid, Nonanoic } \\
\text { acid, 7-Nonenoic acid, Undecanoic acid, Dodecanoic } \\
\text { acid, Tridecanoic acid, Teradecanoic acid, Pentadecanoic } \\
\text { acid, Hexadecanoic acid, n-Octadecenoic acid, } \\
\text { Nonanedioic acid }\end{array}$ & Batch scale & Identified & Identified & [26] \\
\hline
\end{tabular}


Table 1. Cont

\begin{tabular}{|c|c|c|c|c|c|c|c|}
\hline \multirow[b]{2}{*}{ Location } & & \multirow[b]{2}{*}{$\begin{array}{l}\text { Ozonation Conditions and } \\
\text { Water Characteristics }\end{array}$} & \multirow[b]{2}{*}{ Carboxylic Acids (CAs) } & \multirow[b]{2}{*}{$\begin{array}{l}\text { Experiment } \\
\text { Type }\end{array}$} & \multicolumn{2}{|c|}{ Estimated Concentrations of CAs } & \multirow[b]{2}{*}{ Ref. } \\
\hline & & & & & $\begin{array}{l}\text { Raw Water (Total: } \\
\text { Minimum to } \\
\text { Maximum) }\end{array}$ & $\begin{array}{l}\text { Ozonated Water } \\
\text { (Total: Minimum to } \\
\text { Maximum) }\end{array}$ & \\
\hline 13 & $\begin{array}{l}\text { Mississippi River } \\
\text { water }\end{array}$ & $\begin{array}{l}\text { TOC- } 2.72 .6,3.7 \text { and } 3.0 \mathrm{mg} / \mathrm{L} \text {; } \\
\text { alkalinity: } 102,110,112 \text { and } \\
140 \mathrm{mg} / \mathrm{L} \text {; ozone dose: } 2.1,4.3 \text {, } \\
3.0 \text { and } 4.3 \mathrm{mg} / \mathrm{L} \text {. }\end{array}$ & $\begin{array}{l}\text { 2-methylpropanoic acid, butanoic acid, } \\
\text { 3-methlbutanoic acid, pentanoic acid, hexanoic acid, } \\
\text { heptanoic acid, octanoic acid, nonanoic acid, decanoic } \\
\text { acid, undecanoic acid, dodecanoic acid, tridecanoic acid, } \\
\text { tetradecanoic acid, pentadecanoic acid, hexadecanoic } \\
\text { acid, heptadecanoic acid, octadecanoic acid, } \\
\text { phenylacetic acid, benzoic acid, ethanedioic acid, } \\
\text { propanedioic acid, butanedioic acid, } \\
\text { 2-ethyl-3-methylmaleic acid, tert-butylmaleic acid, } \\
\text { pentanedioic acid, hexanedioic acid, heptanedioic acid, } \\
\text { octanedioic acid, nonanedioic acid, decanedioic acid, } \\
\text { undecanedioic acid, tridecanedioic acid, phthalic acid, } \\
\text { isophthalic acid, terephthalic acid, } \\
\text { 1,2,4-benzenetricarboxylic acid, } \\
\text { 1,3,5-benzenetricarboxylic acid, 1,2,4,5- } \\
\text { benzenetetracarboxylic acid, } \\
\text { 1,2,3,4-benzenetetracarboxylic acid, } \\
\text { 1,2,3,5-benzenetetracarboxylic acid }\end{array}$ & Batch scale & Identified & Identified & [9] \\
\hline \multirow{3}{*}{14} & \multirow{3}{*}{$\begin{array}{l}\text { surface water } \\
\text { treatment plant } \\
\text { located in SE Spain }\end{array}$} & \multirow{3}{*}{ Ozonation and chlorination } & 18 (Spring) & \multirow{3}{*}{ Full scale } & $0.02-20(35.76) \mu \mathrm{g} / \mathrm{L}$ & $0.52-75(268) \mu \mathrm{g} / \mathrm{L}$ & \multirow{3}{*}{ [36] } \\
\hline & & & 18+o-Toluic acid (winter) & & $0.02-25(59.5) \mu \mathrm{g} / \mathrm{L}$ & $0.72-100(467.7) \mu \mathrm{g} / \mathrm{L}$ & \\
\hline & & & $\begin{array}{l}\text { Acetic acid, butyric acid, decanoic acid, dodecanoic acid, } \\
\text { glycolic acid, propanoic acid (summer) }\end{array}$ & & $0.04-2.4(3.2) \mu \mathrm{g} / \mathrm{L}$ & $0.13-3.6(5.5) \mu \mathrm{g} / \mathrm{L}$ & \\
\hline 15 & $\begin{array}{l}\text { Full-scale ozone } \\
\text { treatment } \\
\text { plant in Valdosta, GA; } \\
\text { pilot ozonation plant } \\
\text { in Jefferson Parish, LA }\end{array}$ & $\begin{array}{l}\text { Ozone dose of 2:1 } \\
\text { (ozone:dissolved organic } \\
\text { carbon) }\end{array}$ & $\begin{array}{l}\text { 2-methyl propanoic acid, butanoic acid, 3-methyl } \\
\text { butanoic acid, pentanoic acid, hexanoic acid, heptanoic } \\
\text { acid, octanoic acid, nonanoic acid, decanoic acid, } \\
\text { undecanoic acid, dodecanoic acid, tridecanoic acid, } \\
\text { tetradecanoic acid, pentadecanoic acid, hexadecanoic } \\
\text { acid, heptadecanoic acid, octadecanoic acid, } \\
\text { phenylacetic acid, benzoic acid, ethanedioic acid, } \\
\text { propanedioic acid, butanedioic acid, 2-ethyl-3-methyl } \\
\text { maleic acid, tert-butyl maleic acid, pentanedioic acid, } \\
\text { hexanedioic acid, heptanedioic acid, octanedioic acid, } \\
\text { nonanedioic acid, decanedioic acid, undecanedioic acid, } \\
\text { tridecanedioic acid, phthalic acid, isophthalic acid, } \\
\text { terephthalic acid, 1,2,4-benzenetricarboxylic acid, } \\
\text { 1,3,5-benzenetricarboxylic acid, } \\
\text { 1,2,4,5-benzenetetracarboxylic acid, } \\
\text { 1,2,3,4-benzenetetracarboxylic acid, } \\
\text { 1,2,3,5-benzenetetracarboxylic acid }\end{array}$ & Full scale & No data & Identified & [37] \\
\hline
\end{tabular}


Table 1. Cont.

\begin{tabular}{|c|c|c|c|c|c|c|c|}
\hline \multirow[b]{2}{*}{ Location } & & \multirow[b]{2}{*}{$\begin{array}{l}\text { Ozonation Conditions and } \\
\text { Water Characteristics }\end{array}$} & \multirow[b]{2}{*}{ Carboxylic Acids (CAs) } & \multirow[b]{2}{*}{$\begin{array}{l}\text { Experiment } \\
\text { Type }\end{array}$} & \multicolumn{2}{|c|}{ Estimated Concentrations of CAs } & \multirow[b]{2}{*}{ Ref. } \\
\hline & & & & & $\begin{array}{l}\text { Raw Water (Total: } \\
\text { Minimum to } \\
\text { Maximum) }\end{array}$ & $\begin{array}{l}\text { Ozonated Water } \\
\text { (Total: Minimum to } \\
\text { Maximum) }\end{array}$ & \\
\hline 16 & $\begin{array}{l}\text { Full-scale drinking } \\
\text { water treatment plants } \\
\text { located in Spain }\end{array}$ & Ozone and chlorine treatment & $\begin{array}{l}\text { Acetic acid, Propionic acid, Butyric acid, } \\
\text { 2-Methylbutyric acid, Hexanoic acid, Decanoic acid, } \\
\text { Dodecanoic acid, Oleic acid, Oxalic acid, Pyruvic acid, } \\
\text { Glycolic acid, Benzoic acid, o-Toluic acid, m-Toluic acid, } \\
\text { p-Toluic acid, Phenylacetic acid, Salicylic acid, } \\
\text { 3-Hydroxybenzoic acid, 2-Nitrobenzoic acid, } \\
\text { 4-Nitrobenzoic acid, Phthalic acid, } \\
\text { 1,2,3-Benzenetricarboxylic acid }\end{array}$ & Full scale & $44.87-95.47 \mu \mathrm{g} / \mathrm{L}$ & $937-1827 \mu \mathrm{g} / \mathrm{L}$ & [38] \\
\hline 16 & $\begin{array}{l}\text { Natural surface water, } \\
\text { Lake Washington }\end{array}$ & $\begin{array}{l}\text { DOC: } 1.6 \mathrm{mg} / \mathrm{L} \text {; ozone dose: } \\
5.0 \mathrm{mg} / \mathrm{L} ; \text { contact time: } 30 \\
\text { min. }\end{array}$ & Acetic acid, formic acid, oxalic acid & Batch scale & No data & $970 \mu \mathrm{g} / \mathrm{L}$ & [13] \\
\hline \multirow[t]{3}{*}{17} & $\begin{array}{l}\text { Lake water, Lake } \\
\text { Zurich }\end{array}$ & $\begin{array}{l}\text { DOC: } 1.2-1.4 \mathrm{mg} / \mathrm{L} ; \text { ozone } \\
\text { dose: } 2 \pm 0.1 \mathrm{mg} / \mathrm{L} ; \mathrm{pH} \text { : } \\
\text { 7.9-8.0; alkalinity: } 2.6 \mathrm{mmol} / \mathrm{L} ; \\
\text { contact time: } 3.5 \mathrm{~min} .\end{array}$ & $\begin{array}{l}\text { Acetic acid, formic acid, oxalic acid, pyruvic acid, } \\
\text { glyoxalic acid }\end{array}$ & Batch scale & No data & $50 \mu \mathrm{g} / \mathrm{L}$ & \multirow[t]{2}{*}{ [16] } \\
\hline & $\begin{array}{l}\text { Lake water, Lake } \\
\text { Greifensee }\end{array}$ & $\begin{array}{l}\mathrm{pH}=8.6-8.7 ; \mathrm{DOC}=3.9-4.0 \\
\mathrm{mg} / \mathrm{L} ; \text { alkalinity }=2.6 \mathrm{mmol} / \mathrm{L} ; \\
\text { ozone dose: } 2 \pm 0.1 \mathrm{mg} / \mathrm{L} ; \\
\text { contact time: } 3.5 \mathrm{~min} .\end{array}$ & $\begin{array}{l}\text { Acetic acid, formic acid, oxalic acid, pyruvic acid, } \\
\text { glyoxalic acid }\end{array}$ & Batch scale & No data & $150 \mu \mathrm{g} / \mathrm{L}$ & \\
\hline & $\begin{array}{l}\text { Drinking water } \\
\text { treatment facility, } \\
\text { Lengg, Zurich, } \\
\text { Switzerland }\end{array}$ & $\begin{array}{l}\text { Ozone dose } \\
1.1 \mathrm{mg} / \mathrm{L} ; \\
\text { contact time: } 50 \mathrm{~min} .\end{array}$ & $\begin{array}{l}\text { Acetic acid, formic acid, oxalic acid, pyruvic acid, } \\
\text { glyoxalic acid }\end{array}$ & Full scale & $0-4 \mu \mathrm{g} / \mathrm{L}(7 \mu \mathrm{g} / \mathrm{L})$ & $0-7 \mu \mathrm{g} / \mathrm{L}(12.5 \mu \mathrm{g} / \mathrm{L})$ & \\
\hline \multirow{4}{*}{18} & \multirow{4}{*}{$\begin{array}{l}\text { Drinking water } \\
\text { treatment plants } \\
\text { located in Taihu Lake } \\
\text { Region, China }\end{array}$} & \multirow{4}{*}{ Ozonation } & $\begin{array}{l}\text { Spring: Formic acid, oxalic acid, malonic acid, fumaric } \\
\text { acid, phthalic acid, benzoic acid, protocatechuic acid, } \\
\text { 3-hydroxy benzoic acid }\end{array}$ & \multirow{4}{*}{ Full scale } & $\begin{array}{l}\text { ND-154.2 } \\
(227.6-345.6) \mu \mathrm{g} / \mathrm{L}\end{array}$ & $\begin{array}{l}\text { ND- } 159.7 \\
(483.4-782.56) \mu g / L\end{array}$ & \multirow{4}{*}{ [39] } \\
\hline & & & $\begin{array}{l}\text { Summer: Acetic acid, fumaric acid, benzoic acid, } \\
\text { protocatechuic acid, 3-hydroxy benzoic acid }\end{array}$ & & $\begin{array}{l}\text { ND-214.16 } \\
(344.64-533.31) \mu \mathrm{g} / \mathrm{L}\end{array}$ & $\begin{array}{l}\text { ND-268.3 } \\
(311.4-858.5) \mu \mathrm{g} / \mathrm{L}\end{array}$ & \\
\hline & & & $\begin{array}{l}\text { Autumn: Formic acid, acetic acid, fumaric acid, benzoic } \\
\text { acid, protocatechuic acid, 3-hydroxy benzoic acid }\end{array}$ & & $\begin{array}{l}\text { ND-212.12 } \\
(296.45-633.27) \mu \mathrm{g} / \mathrm{L}\end{array}$ & $\begin{array}{l}\text { ND-158.4 } \\
(300-631.76) \mu \mathrm{g} / \mathrm{L}\end{array}$ & \\
\hline & & & $\begin{array}{l}\text { Winter: Formic acid, oxalic acid, fumaric acid, phthalic } \\
\text { acid, benzoic acid, protocatechuic acid, 3-hydroxy } \\
\text { benzoic acid }\end{array}$ & & $\begin{array}{l}\text { ND-130.75 } \\
(241.69-301.22) \mu \mathrm{g} / \mathrm{L}\end{array}$ & $\begin{array}{l}\text { ND-139.65 } \\
(304.56-632.68) \mu g / L\end{array}$ & \\
\hline
\end{tabular}

$\mathrm{CaCO}_{3}$ : Calcium carbonate; ND: Not detectable; TOC: Total organic carbon; DOC: Dissolved organic carbon; ng/L: Nanogram/liter; $\mu \mathrm{g} / \mathrm{L}: \mathrm{Microgram} / \mathrm{liter}$; No data: Not reported/not measured; Identified: Qualitative measurement was done. 


\subsection{Parameters Effecting the Formation of $C A B P S$}

\subsubsection{Ozone Dose and Organic Carbon}

As shown in Table 1 (row no. 8), Gagnon et al. [33] studied the effects of ozone dose (1.8-4 mg/L), organic carbon $(4-6.3 \mathrm{mg} / \mathrm{L})$ and temperature $\left(2.8-22{ }^{\circ} \mathrm{C}\right)$ on six short-chain CABPs undergoing full-scale ozonation in the Mannheim Water Treatment Plant in Kitchener, Ontario [34]. Among the six CABPs, only glycolic acid formation $(33-49 \mu \mathrm{g} / \mathrm{L})$ showed significant correlations with temperature $\left(2.8-22^{\circ} \mathrm{C}\right)$ and ozone dose $(1.8-4 \mathrm{mg} / \mathrm{L})$ but not with the studied range of organic carbon concentrations $(4-6.3 \mathrm{mg} / \mathrm{L})$. The authors have therefore deduced that the studied levels of organic carbon were not rate-limiting parameters or they were not present at levels sufficient for affecting CABP formation. This study also confirmed that the CABP yield was ten times that of aldehyde DBPs. However, Griffini et al. [23] reported a linear relationship $(R=0.91)$ between the formation of total DBPs (aldehydes and CAs), dissolved organic carbon (DOC) and ozone dose. Griffini et al. [23] also reported that the formation of ketoacids was twice that of aldehyde BPs. To understand the effect of ozone dosage on the type of formed CABPs, Huang et al. [26] applied ozonation to water from Feng-San Reservoir $(\mathrm{DOC}=3.0$ to $3.5 \mathrm{mg} / \mathrm{L}$ ). This study reported low concentrations of aromatic CABPs at low ozone doses and high concentrations of aliphatic CABPs at high ozone doses. This indicates the oxidation of aromatic CABPs into aliphatic CABPs with increasing doses of ozone $(0.5$ to $11 \mathrm{mg} \mathrm{O} / \mathrm{mg}$ DOC). Similarly, Richardson et al. [9] identified higher levels of CABPs than other DBPs when water from the Mississippi River was subjected to four rounds of ozonation. Liu et al. [13] also reported a linear relationship between CABPs formation and ozone dose $(0-5 \mathrm{mg} / \mathrm{L})$ during ozonation of Lake Washington water. All these studies confirm the high levels of the formation of CA DBPs by ozonation and their increase when ozone dose is increased. However, these studies did not determine the mechanism for the formation of CABPs with respect to NOM composition and concentration and ozonation conditions (dose and contact time).

\subsubsection{Temperature}

Philip Porter [30] conducted a study to understand the impact of change in water quality with season on ODBP formation using clarified water collected from the Britannia Water Purification Facility in Ottawa, Canada. This study also studied the range of temperature effect on ODBPs formation, 7 and $22{ }^{\circ} \mathrm{C}$ for summer water matrix and $11^{\circ} \mathrm{C}$ for fall water matrix at different $\mathrm{pH}$ values $(6$ and 8$)$ and at different scales (pilot, semi-batch and flow-through) (Table 1, row no. 5). This study revealed that the concentration of CABPs (formic acid $(38.8 \%)$, acetic acid $(37.4 \%)$, glycolic $(11.7 \%)$ and pyruvic acid $(12.3 \%))$ was 5 to 10 times the average of total aldehyde BPs. An increase in total CABP formation was reported in summer water, compared to fall water. This difference in CABP formation could be due to the seasonal changes in the raw water matrix and temperature (as shown in Table 1, row no. 5). No change was observed in the formation of CABPs during ozonation of summer water at a temperature of $22{ }^{\circ} \mathrm{C}$ with a change in $\mathrm{pH}$ from 6 to 8 but a statistically significant increase was observed in the case of fall water ozonation at $11^{\circ} \mathrm{C}$. However, the authors did not provide any logical explanation for the effect of $\mathrm{pH}$ change and temperature on CABPs formation.

Jurado-Sánchez et al. [36] identified 35 CAs in a WTP located in Southeastern Spain over three different seasons (summer, winter and spring). The higher levels of CABPs in raw water samples collected in winter and spring compared to samples collected in summer are shown in Table 1 (row no.14). This significant seasonal variation in raw water CAs could be due to changes in NOM composition and concentration. The high concentration of CAs in raw water during winter and spring indicate/reveal the effect of rainfall on raw water composition. The biodegradation and thermal or photo-degradation of CAs in the summer may be responsible for the low concentrations observed in raw water. Compared to raw water concentrations, ozonation increased total CABP levels to almost 7.5 times in winter and spring and 0.5 times in summer. Among the recorded CABPs, the formation of aromatic CABPs increased up to $60 \%$. These differences in total CABPs are primarily due to seasonal 
variations in the composition of the organic matrix. Similar results indicating higher levels of CABP formation were obtained in spring and winter during the ozonation of water from the Taihu Lake Region in China, by Zhong et al. [39]. Seasonal variations in NOM and water temperature may significantly affect the CAs levels in raw water and the corresponding CABPs formation but the effect of temperature on CABPs formation during ozonation has not yet been reported. More research is needed to confirm the effects of temperature on CABP formation. Research in this area may be useful for optimizing ozonation conditions in countries with colder temperatures.

\subsection{Occurrence of $C A B P S$}

Glaze et al. [29] (Table 1, row no. 1) observed differences in the type and quantity of CABPs in raw and ozonated waters from the Los Angeles Aqueduct Water (LAAW) in the Los Angeles Aqueduct Filtration Plant (LAAFP). Short-chain and aromatic (C6-C11) CABPs were not detected in raw water samples but they were detected in ozonated water at concentrations of 27-970 ng/L. These detected CABPs included benzoic acid, hexanoic acid, heptanoic acid, octanoic acid, nonanoic acid, decanoic acid and undecanoic acid. The concentrations of long-chain CABPs, C14-C18 (not detectable (nd) $-3975 \mathrm{ng} / \mathrm{L}$ ) were lowered in raw water (nd-1705 ng/L), indicating that the long-chain CAs have a high reactivity to ozone. This study also found that the unsaturated CABP 9-hexadecenoic acid, which was detected at a high level $(2165 \mathrm{ng} / \mathrm{L})$ in raw water, was not detected in ozonated water. Hence, unsaturated CABPs must be easily oxidized by ozone. Furthermore, laboratory ozonation of 9-hexadecenoic acid has confirmed the formation of different CABPs along with the aldehyde, heptanal. As shown in Table 1 (row no. 1), ozonation reduced the total abundance of CABPs to 55\% compared to raw water. However, ozonation also generated new and short-chain CABPs, which are highly biodegradable [29].

Following this study, another full-scale study and two batch-scale studies were conducted in the same plant (LAAFP) in 1989. These studies aimed to evaluate and compare the ODBPs in State Project Water (SPW) with previously reported results of LAAW [29]. In the full-scale study, only aldehyde BPs were reported for SPW samples, making it impossible to compare CABP results. The batch-scale results for CABPs from these two river waters (LAAW and SPW) were compared and are reported in Table 1 (rows no. 2 and 3, respectively). Raw water samples from both rivers were found to have significant levels of CAs but SPW yielded almost twice the level of LAAW. This could be due to the high concentration of total organic carbon (TOC) $(2.6 \mathrm{mg} / \mathrm{L})$ present as compared to the concentration in LAAW $(1.6 \mathrm{mg} / \mathrm{L})$. For both SPW and LAAW, the ozonated water has lower concentrations of long-chain CABPs and higher concentrations of short-chain CAs than in raw water. In SPW, a remainder of $>50 \%$ unsaturated CA 9-hexadecenoic acid and a $<10 \%$ reduction in total CABPs were observed after ozonation. In LAAW, ozonation resulted in diminished levels of unsaturated CA 9-hexadecenoic acid and a reduction in total CABPs to $44 \%$. This difference in results could be due to the higher concentration of TOC (1.6 times) and the higher initial concentration of 9-hexadecenoic acid (2.8 times) in SPW compared to LAAW at the administered ozone dose.

In 2012, a study by Jurado-Sánchez et al. [38] identified 22 CAs in two full-scale drinking water plants in Spain, where a combination of ozonation with chlorination and chlorination alone were applied for disinfection. The combined (ozonation and chlorination) treatment resulted in an increase of 19-20 times (Table 1, row no. 16) the total CABP concentrations in treated water compared to raw water. However, chlorination alone showed nearly no change in total CABPs. This might explain the catalytic role of chlorine disinfection in CABP formation. Among the 22 CAs measured, a significant increase was observed after ozonation for acetic acid, oxalic acid, glycolic acid, benzoic acid, phthalic acid and 1,2,3 benzoic acids [38]. Similar results were obtained by Nawrocki et al. [35] who applied ozonation to the Warta River water in Poland. They observed the levels of total formic and oxalic acid formation that were ten times higher than those of total aldehydes (formaldehyde, acetaldehyde, glyoxal and methylglyoxal) [35]. These results are similar to those from previous studies by Porter [30] and Huang et al. [26]. 
To date, many studies have reported the high prevalence of specific CABPs such as acetic acid, glyoxylic acid and oxalic acid in drinking water, as shown in Table 1 (rows no. 4-11 and 17). Predominantly, acetic acid, glyoxylic acid and oxalic acid were generated (around 47-75\%) when water from the Feng-San Reservoir (DOC3-3.5 mg/L) was subjected to ozonation [26]. Another study reported oxalic acid as being the principal by-product of all CABPs, accounting for $50 \%$ of total CABPs $[40,41]$. Propanol, commonly present in raw water samples [42], was subjected to ozonation in order to demonstrate the principal formation of the three CABPs (acetic acid, glyoxylic acid and acid) at lab-scale. Through ozonation, propanol was converted into acetic acid and oxalic acid. Acetic acid was oxidized into glyoxylic acid which in turn, was oxidized into oxalic acid. Acetic acid $\left(\mathrm{C}_{2} \mathrm{H}_{2} \mathrm{O}_{2}\right)$ and glyoxylic acid $\left(\mathrm{C}_{2} \mathrm{H}_{2} \mathrm{O}_{3}\right)$ were further oxidized by ozone to increase the number of oxygen atoms in their structures and form oxalic acid. Oxalic acid was subsequently oxidized to carbon dioxide and water [43]. Hence, through ozonation, the compounds with functional groups including $-\mathrm{OH},=\mathrm{O},=$ $\mathrm{CHO}$ and $=\mathrm{COOR}$ undergo oxidation multiple times and are converted into their most oxidized forms with a carboxylic acid functional group. These CAs further undergo oxidation or mineralization based on the ozone dose and contact time. All of this suggests that CAs might be the most significant type of DBP resulting from ozonation disinfection.

There are few studies on the removal of CABPs in WTPs. Of the existing studies, Glaze et al. [29] compiled data from SPW in California that demonstrated the presence of total residual CABPs $(1961 \mathrm{ng} / \mathrm{L})$ in finished water after anthracite filtration compared to other ODBPs, such as aldehydes which were not detected (Figure 1). Similarly, the CABPs (formic and acetic acid) that formed in high concentrations ( $40 \%$ of total CABPs $490 \mu \mathrm{g} / \mathrm{L}$ ) were efficiently removed $(>80 \%$ ) by biologically active filters. Another CABP (pyruvic acid) which was formed at low levels ( $8 \%$ of total CABPs $490 \mu \mathrm{g} / \mathrm{L}$ ) was removed with poor efficiency $(60 \%)$ [32]. These studies demonstrate that CABP removal varies depending on the type of CABP. Moreover, it is impossible to compare CABP formation and removal among the reported studies, as the treatment conditions, water matrices, concentrations of CABPs, operating conditions and filter properties were all completely different.

To date, most studies have concluded that CAs are the major DBPs that result from ozonation, are formed by the oxidation of NOM and increase with contact time and ozone dose [26]. To the best of our knowledge, the main pathways for CABP formation in drinking water have not been reported. This review highlights the concept that NOM and its oxidized intermediate BPs act as precursors and undergo a large number of redox reactions to form CABPs. The structural and compositional complexity of NOM differs depending on the ozonation conditions and treatment process of each WTP, worldwide. The data reported are therefore diverse in terms of the types and levels of CABPs. Regardless, current research should focus on investigating the relationships between the NOM characteristics (composition and structure), ozonation conditions (ozone dose, contact time) and seasonal variations in order to establish the mechanism of CABP formation and the key factors that affect it.

\section{Analytical Quantification of CABPs}

CAs have a wide range of polarities and molecular weights. They exist in protonated or deprotonated forms depending on the $\mathrm{pH}$ of the source water and $\mathrm{pKa}$ of the CAs. Trace level occurrences of CAs have also posed a challenge to the current analytical tools. Table 2 lists the various instrumental and sample processing technologies and the detection limits for CAs. In general, most of the analytical methods were developed in pure drinking water samples by spiking CA standards to avoid matrix interferences, which in turn, affects the sensitivity of the method [44]. Therefore, factors such as the concentration and type of CA (polarity and molecular weight) and the sample matrix largely determine the accuracy of the analytical method. Matrix interferences can potentially impact the accurate quantification of CAs at trace levels because environmental samples have complex matrix compositions. A few methods, as mentioned in Table 2 (row no. 9, 10,11,14,17), have directly analyzed samples after a simple filtration step. This direct analysis has resulted in low sensitivity $(\mu \mathrm{g} / \mathrm{L}-\mathrm{mg} / \mathrm{L})$ of CAs because of the insufficient removal of the matrix interferences from raw water samples. Clean-up 
and pre-extraction steps are being applied in order to tackle these matrix interferences. Conventional extraction methods, such as liquid-liquid extraction, are applied for specific compounds; however, these methods consume large amounts of solvent and are time- and are labor-intensive. Therefore, these conventional methods may not be the most efficient for extracting CAs. Recent technical developments in sample preparation, such as solid-phase microextraction (SPME), headspace-needle trap extraction and solid-phase extraction (SPE) have been applied to extract a broad range of compounds and to reduce solvent requirements and analytical time. Among these, SPE has gained in popularity due to its simplicity, lower solvent consumption and its ability to extract several compounds [37].

Predominantly, CAs exist as carboxylates (deprotonated, negative ions) due to their low pKa values in comparison to surface water $\mathrm{pH}$. To achieve good sorption and extraction capacities, CAs must be in their protonated (positive ions) forms. To convert CAs to their pronated forms the $\mathrm{pH}$ of water samples is adjusted to 2 or lower. Selecting a sorbent material for SPE is crucial for the efficient adsorption of CAs because of the wide range of polarity among these materials. The sorption capacities of broad-spectrum materials have been investigated by Jurado-Sánchez et al. [44] (Table 2, row no. 23) and include polar materials (silica gel), non-polar materials (Supelclean ENVI-18; silica-reverse phase octadecyl), polymeric materials (Amberlites [XAD-2, XAD-4, XAD-7 and XAD-16], Oasis HLB, HyperSep Retain PEP, Isolute ENV+, LiChrolut EN), graphitized carbon black and fullerenes (C60 and C70 derivatives and nanotubes) [44]. The polar sorbents showed lower sorption capacities $(<30 \%)$ due to weak interactions between CAs and the polar surface of the sorbent. Strong hydrophobic interactions of non-polar sorbents resulted in higher medium retention and long-chain aliphatic and aromatic CAs (over 85\%) and reduced the retention of polar CAs (C2-C5, phenylacetic and phthalic acids). In the case of polymer sorbents, Oasis HLB and LiChrolut EN showed good recovery ( 100\%) of C2-C12 aliphatic and aromatic CAs and less efficient recovery (50-75\%) of long-chain carboxylic acids (C14-C18). Amberlite polymer sorbents showed lower retention for CAs than Oasis HLB and LiChrolut EN sorbents [44]. This study showed the different sorption capacities of polymeric sorbents due to their differences in particle size and polarity. The sorbent materials of carbon derivatives showed an average of retention of CAs (30-70\%) due to their non-polar interactions. Based on these data, an equal ratio of polymeric to non-polar sorbents (LiChrolut EN and Supelclean ENVI-18 (1:1)) has been used to extract a broad range of CAs as shown in Table 2 (row no. 9, 10, 23, 24). Extraction using a combination of sorbents in this way showed good recovery and sensitivity for a wide range of CAs, including short-chain and long-chain aliphatic and aromatic CAs.

In addition to the extraction methods, the instruments and techniques used also determine the sensitivity of analytical methods. Several tools can be used to detect CAs in environmental samples, such as capillary electrophoresis, ion-exchange chromatography, ion-exclusion chromatography, gas chromatography (GC) and liquid chromatography (LC), as shown in Table 2 (row no. 9, 10, 13). GC is the most extensively used technique due to its inherent advantages of simplicity, high sensitivity and selectivity, broad and ease of applicability, low cost and high resolving power. For GC analysis, compounds must have sufficient thermostability and volatility properties; however, only a few CAs meet these criteria. When measuring polar CAs using GC, it is challenging to get high resolution between peaks with a standard capillary GC column due to weak adsorption. Therefore, columns with stationary phases coated with polyethylene glycol or acids have been utilized for improved adsorption and peak resolution of polar CAs (Table 2, row no. 18 and 23). Molecular weight also plays a vital role in GC analysis. While low molecular weight CAs cannot be detected due to the high background noise of the instrument, high molecular weight CAs are difficult to volatilize and analyze. Therefore, studies have applied derivatization methods to make CAs volatile and stable at high temperatures during GC analysis. Various derivatization procedures have been developed, such as alkylation (using induced alkylchloroformate, trimethylammonium hydroxide, trimethylanilinium hydroxide, trimethylphenylammonium hydroxide and alcohols in the presence of BF3 or acetyl chloride as a catalyst) and silylation (using N,O- bis-(trimethylsilyl) trifluoroacetamide (BSTFA) with $1 \%$ trimethylchlorosilane (TMCS) and N,O-bis-(trimethylsilyl) acetamide (BSA)) (Table 2 row no. 3, 
25, 26). Jurado-Sánchez et al. [38] compared the sensitivities of derivatization by alkylation and by silylation. Both derivatization sensitivities were comparable with aliphatic C2-C18 CAs. However, alkylation (BF3 or acetyl chloride catalyst) of aromatic CAs showed low sensitivity compared to silylation of aromatic CAs. In addition, it was observed that the high basicity of alkylating agents accelerated the GC column damage [45]. Silylation reagents showed high sensitivity and produced better yields and derivative stability during GC analysis. Silylated derivatives also generated good resolution peaks due to their high volatility, which leads to reliable identification [38]. All these derivatization methods require high temperatures or longer times to achieve a high percentage yield. Therefore, in order to reduce the reaction time, microwave-assisted derivatization was developed [38]. 
Table 2. Analytical approaches developed for detection of carboxylic acid in water samples.

\begin{tabular}{|c|c|c|c|c|c|}
\hline & Carboxylic Acids (CAs) & Instrument Type & Sample Preparation & Detection Limit & References \\
\hline 1 & $\begin{array}{l}\text { Acetic, propionic, butyric, valeric, hexanoic, hep tanoic, } \\
\text { octanoic, nonanoic, decanoic acid }\end{array}$ & GC-FID & $\begin{array}{l}\text { Solid phase microextraction } \\
\text { followed by derivatization } \\
\text { (l-pyrenyldiazomethane) }\end{array}$ & Identified & [46] \\
\hline 2 & \multirow{2}{*}{ Acetic acid, propionic acid, butyric acid, valeric acid } & GC-FID & Solid phase microextraction & $3.1-760 \mu \mathrm{g} / \mathrm{L}$ & \multirow{2}{*}[47,48]{} \\
\hline 3 & & GC-ECD & $\begin{array}{l}\text { Derivatization with } \\
\text { Pentafluorobenzyl bromide and } \\
\text { (pentafluorophenyl)diazoethane }\end{array}$ & $0.4-0.8 \mu \mathrm{g} / \mathrm{L}$ & \\
\hline 4 & $\begin{array}{l}\text { 2-methylpropanoic acid, butanoic acid, 3-methylbutanoic acid, } \\
\text { pentanoic acid, hexanoic acid, heptanoic acid, octanoic acid, } \\
\text { nonanoic acid, decanoic acid, undecanoic acid, dodecanoic acid, } \\
\text { tridecanoic acid, tetradecanoic acid, pentadecanoic acid, } \\
\text { hexadecanoic acid, heptadecanoic acid, octadecanoic acid, } \\
\text { phenylacetic acid, benzoic acid, ethanedioic acid, propanedioic } \\
\text { acid, butanedioic acid, 2-ethyl-3-methylmaleic acid, } \\
\text { tert-butylmaleic acid, pentanedioic acid, hexanedioic acid, } \\
\text { heptanedioic acid, octanedioic acid, nonanedioic acid, } \\
\text { decanedioic acid, undecanedioic acid, tridecanedioic acid, } \\
\text { phthalic acid, isophthalic acid, terephthalic acid, } \\
\text { 1,2,4-benzenetricarboxylic acid, 1,3,5-benzenetricarboxylic acid, } \\
\text { 1,2,4,5- benzenetetracarboxylic acid, } \\
\text { 1,2,3,4-benzenetetracarboxylic acid, } \\
\text { 1,2,3,5-benzenetetracarboxylic acid }\end{array}$ & GC/MS, fused-silica column & $\begin{array}{l}\text { Methylation } \\
\text { derivatizations with } \\
\text { BF3-methanol }\end{array}$ & Identified & [9] \\
\hline 5 & $\begin{array}{l}\text { Hexanoic acid, heptanoic acid, benoic acid, octanoic acid, } \\
\text { nonanoic acid, decanoic acid, undecanoic acid, dodecanoic acid, } \\
\text { tridecanoic acid, pentadecanoic acid, tetradecanoic acid, } \\
\text { 9-hexadecenoic acid, hexadecenoic acid, heptadecanoic acid, } \\
\text { octadecanoic acid, nonadecanoic acid, eicosanoic acid, } \\
\text { Heneicosanoic acid, docosanoic acid, tricosanoic acid, } \\
\text { tetracosanoic acid }\end{array}$ & GC/MS, fused-silica column & $\begin{array}{l}\text { Closed loop stripped analysis } \\
\text { using Granular activated } \\
\text { carbon as cartridge }\end{array}$ & Quantified & [29] \\
\hline 6 & $\begin{array}{l}\text { Hexanoic acid, heptanoic acid, benoic acid, octanoic acid, } \\
\text { nonanoic acid, decanoic acid, undecanoic acid, dodecanoic acid, } \\
\text { tridecanoic acid, pentadecanoic acid, tetradecanoic acid, } \\
\text { 9-hexadecenoic acid, hexadecenoic acid, heptadecanoic acid, } \\
\text { octadecanoic acid, nonadecanoic acid, eicosanoic acid, } \\
\text { Heneicosanoic acid, docosanoic acid, tricosanoic acid, } \\
\text { tetracosanoic acid }\end{array}$ & GC/MS, fused-silica column & $\begin{array}{l}\text { Non-ionic resin accumulation } \\
\text { and methylation using } \\
\text { diazomethane-ether solution }\end{array}$ & Quantified & [49] \\
\hline
\end{tabular}


Table 2. Cont

\begin{tabular}{|c|c|c|c|c|c|}
\hline & Carboxylic Acids (CAs) & Instrument Type & Sample Preparation & Detection Limit & References \\
\hline 7 & $\begin{array}{l}\text { Hexanoic acid, heptanoic acid, benzoic acid, octanoic acid, } \\
\text { nonanoic acid, phthalic acid, decanoic acid, undecanoic acid, } \\
\text { dodecanoic acid, tridecanoic acid, tetradecanoic acid, } \\
\text { hexadecenoic acid, heptadecanoic acid, octadecanoic acid }\end{array}$ & GC/FT-IR, Restek Rtx-5 column & $\begin{array}{l}\text { Sample concentration by } \\
\text { adsorption on Amberlite XAD } \\
\text { resins }\end{array}$ & Quantified & [50] \\
\hline 8 & $\begin{array}{l}\text { Glyoxylic acid, pyruvic } \\
\text { acid, ketomalonic acid }\end{array}$ & $\begin{array}{l}\text { GC-ECD, GC-EI, 30-m x 0.32-mm, } \\
0.25-\mathrm{mm} \text { SPB-5 capillary column. }\end{array}$ & $\begin{array}{l}\text { PFBHA-diazomethane double } \\
\text { derivatization }\end{array}$ & $0.5 \mu \mathrm{g} / \mathrm{L}$ & {$[22]$} \\
\hline 9 & Formic acid, acetic acid, glycolic acid, pyruvic acid, & IC-DC; Dionex AS 10-25Ox4mm & Direct injection & Quantified & [30] \\
\hline 10 & $\begin{array}{l}\text { Acetic acid, glycolic acid, butyric acid, formic acid, ketobutyric } \\
\text { acid, pyruvic acid }\end{array}$ & IC-CDM; anion-exchange column & $\begin{array}{l}\text { Direct injection (large sample } \\
\text { loop: } 740 \mu \mathrm{l} \text { ) }\end{array}$ & 1 to $5 \mu \mathrm{g} / \mathrm{L}$ & {$[33]$} \\
\hline 11 & Oxalic acid & IC & $\begin{array}{l}740 \mathrm{ml} \text { sample loop (direct } \\
\text { injection) } \\
\text { concentrator column (heart-cut) }\end{array}$ & $\begin{array}{c}9 \mu \mathrm{g} / \mathrm{L} \text { (direct) } \\
6 \mu \mathrm{g} / \mathrm{L} \text { (heart-cut) }\end{array}$ & [51] \\
\hline 12 & $\begin{array}{l}\text { Acetic acid, propionic acid, formic acid, pyruvic acid, glyoxylic } \\
\text { acid, oxalic acid and ketomalonic acid. }\end{array}$ & IC; Dionex 2000 & $\begin{array}{l}\text { hydrogen cartridge } \\
\text { (OnGuard-H+, P/N 39596; } \\
\text { Dionex) }\end{array}$ & $2-6 \mu \mathrm{g} / \mathrm{L}$ & [32] \\
\hline 13 & $\begin{array}{l}\text { Glyoxylic acid, pyruvic acid, ketomanoic acid, 5-ketohexanoic } \\
\text { acid, oxalacetic acid }\end{array}$ & $\begin{array}{l}\text { LC-MS/MS } \\
\text { spectrometer-Electrospray ionization; } \\
\text { Supelco Supelcosil C18 LC column }\end{array}$ & $\begin{array}{l}\text { Derivatization with DNPH } \\
\text { followed by solid phase } \\
\text { extraction using C-18 Empore } \\
\text { disk ( } 3 \text { M Corp.) }\end{array}$ & Identified & [34] \\
\hline 14 & Formic and oxalic acid & $\begin{array}{l}\text { Ion chromatography; DIONEX } \\
\text { DX-500 system with IonPac AS-9-HC } \\
\text { column; conductivity detector }\end{array}$ & Direct injection & Quantified & [35] \\
\hline 15 & $\begin{array}{l}\text { Glyoxylic acid, acetic acid, oxalic acid, pyruvic acid, } \\
\text { 2-methylpropanoic acid, butanoic acid, 3-methylbutanoic acid, } \\
\text { benzoic acid, 2-hydroxylbenzoic acid, phthalic acid and } \\
\text { nitrobenzoic acid }\end{array}$ & GC/EI-MS, DB-1 column & $\begin{array}{l}\text { Pentafluorobenzylhydroxylamine } \\
\text { (PFBHA) derivatization }\end{array}$ & Quantified & {$[13,26]$} \\
\hline 16 & $\begin{array}{l}\text { Acetic acid, Formic acid, } \\
\text { Propanoic acid, isobutyric Acid, Butanoic acid, Isovaleric acid, } \\
\text { n-Valeric acid, Isocaproic acid, n-Caproic acid, Heptanoic acid }\end{array}$ & $\begin{array}{l}\text { GC/MS; Stablewax DA fused-silica } \\
\text { capillary column }\end{array}$ & Fiber adsorption & $0.03-11.5 \mathrm{mM} / \mathrm{L}$ & [52] \\
\hline 17 & $\begin{array}{l}\text { Acetic acid, } \\
\text { Propionic acid, Isobutyric acid, n-Butyric acid, Isovaleric acid, } \\
\text { n-Valeric acid }\end{array}$ & $\begin{array}{l}\text { HS-GC, a free fatty acid phase (FFAP) } \\
\text { fused-silica capillary column }\end{array}$ & Direct injection & $0.1-4.1 \mathrm{mg} / \mathrm{L}$ & [53] \\
\hline
\end{tabular}


Table 2. Cont

\begin{tabular}{|c|c|c|c|c|c|}
\hline & Carboxylic Acids (CAs) & Instrument Type & Sample Preparation & Detection Limit & References \\
\hline 18 & $\begin{array}{l}\text { Acetic acid, } \\
\text { Propionic acid, Butyric acid, Valeric acid, Hexanoic acid, } \\
\text { Heptanoic acid }\end{array}$ & $\begin{array}{l}\text { GC-CI-MS; GC-FID; a tailor-made } \\
\text { capillary column coated with } \\
\text { polyethylene glycol modified with } \\
\text { nitroterephthalic acid }\end{array}$ & $\begin{array}{l}\text { Headspace solid-phase } \\
\text { microextraction using } \\
\text { polydimethylsiloxane-Carboxen } \\
\text { fiber extraction }\end{array}$ & $\begin{array}{l}150 \mu \mathrm{g} / \mathrm{L} \text { (acetic acid); } 2 \text { to } \\
6 \mu \mathrm{g} / \mathrm{L} \text { (for remaining } \\
\text { CAs)-GC-MS; } 675 \mu \mathrm{g} / \mathrm{L} \\
\text { (acetic acid); } \\
6-54 \mu \mathrm{g} / \mathrm{L} \text { (for remaining } \\
\text { CAs)-GC-FID }\end{array}$ & {$[54,55]$} \\
\hline 19 & $\begin{array}{l}\text { Aliphatic carboxylic acids (formic, acetic, propionic, butyric, } \\
\text { isovaleric, valeric, isocaproic, } 17 \text { caproic, 2-methylhexanoic } \\
\text { and heptanoic acids) and benzenecarboxylic acids (pyromellitic, } \\
\text { trimellitic, hemimellitic, o-phthalic, m-phthalic, p-phthalic, } \\
\text { benzoic, salicylic acids and phenol) }\end{array}$ & Ion-exclusion chromatography & $\begin{array}{l}\text { Different resin extractions: } \\
\text { sulfonated silica gel; } \\
\text { carboxylated silica gel; } \\
\text { sulfonated polymethacrylate } \\
\text { resin; carboxylated } \\
\text { polymethacrylate resins }\end{array}$ & Identified & [56] \\
\hline 20 & $\begin{array}{l}\text { Formic, acetic, oxalic acid, malonic acid-ICS; fumaric, } \\
\text { protocatechuic, 3-hydroxybenzoic, phthalic and benzoic } \\
\text { acid-UHPLC }\end{array}$ & $\begin{array}{c}\text { ICS-2100, Dionex IonPac AS-19 } \\
\text { capillary column; } \\
\text { ultra-high-performance liquid } \\
\text { chromatography, BEH C18 column }\end{array}$ & $\begin{array}{l}\text { SPE: } 80 \mathrm{mg} \text { of the mixture } \\
\text { LiChrolut EN/Supelclean } \\
\text { ENVI-18 (1:1) sorbents - } \\
\text { UHPLC } \\
\text { Direct injection -ICS }\end{array}$ & Quantified & [39] \\
\hline 21 & $\begin{array}{l}\text { 2-methyl propanoic acid, butanoic acid, 3-methyl butanoic acid, } \\
\text { pentanoic acid, hexanoic acid, heptanoic acid, octanoic acid, } \\
\text { nonanoic acid, decanoic acid, undecanoic acid, dodecanoic acid, } \\
\text { tridecanoic acid, tetradecanoic acid, pentadecanoic acid, } \\
\text { hexadecanoic acid, heptadecanoic acid, octadecanoic acid, } \\
\text { phenylacetic acid, benzoic acid, ethanedioic acid, propanedioic } \\
\text { acid, butanedioic acid, 2-ethyl-3-methyl maleic acid, tert-butyl } \\
\text { maleic acid, pentanedioic acid, hexanedioic acid, heptanedioic } \\
\text { acid, octanedioic acid, nonanedioic acid, decanedioic acid, } \\
\text { undecanedioic acid, tridecanedioic acid, phthalic acid, } \\
\text { isophthalic acid, terephthalic acid, 1,2,4-benzenetricarboxylic } \\
\text { acid, 1,3,5-benzenetricarboxylic acid, } \\
\text { 1,2,4,5-benzenetetracarboxylic acid, } \\
\text { 1,2,3,4-benzenetetracarboxylic acid, } \\
\text { 1,2,3,5-benzenetetracarboxylic acid }\end{array}$ & $\begin{array}{l}\text { GC/EI-MS, DB- } 5 \text { column; LC/MS, } \\
\text { Supelco Supelcosil C18 LC column; } \\
\text { GC/IR, Restek Rtx-5 column }\end{array}$ & $\begin{array}{l}\text { Adsorption: XAD resin } \\
\text { extraction; Derivalization: } \\
\text { pentafluorobenzylhydroxylamine } \\
\text { (PFBHA)-GC-MS; } \\
\text { 2,4-dinitrophenylhydrazine } \\
\text { (DNPH) - LC-MS }\end{array}$ & Identified & [37] \\
\hline
\end{tabular}


Table 2. Cont

\begin{tabular}{|c|c|c|c|c|c|}
\hline & Carboxylic Acids (CAs) & Instrument Type & Sample Preparation & Detection Limit & References \\
\hline 22 & $\begin{array}{l}\text { Acetic acid, Propionic acid, Butyric acid, 2-Methylbutyric acid, } \\
\text { Valeric acid, Isovaleric acid, Hexanoic acid, Octanoic acid, } \\
\text { Nonanoic acid, Decanoic acid, Dodecanoic acid, Myristic acid, } \\
\text { Palmitic acid, Heptadecanoic acid, Stearic acid, Oleic acid, } \\
\text { Linoleic acid, Oxalic acid, Pyruvic acid, Glycolic acid, Succinic } \\
\text { acid, Fumaric acid, Benzoic acid, o-Toluic acid, m-Toluic acid, } \\
\text { p-Toluic acid, Phenylacetic acid, Salicylic acid, } \\
\text { 3-Hydroxybenzoic acid, 2-Nitrobenzoic acid, 3-Nitrobenzoic } \\
\text { acid, 4-Nitrobenzoic acid, 3,4-Dihydroxybenzoic acid, Phthalic } \\
\text { acid, 1,2,3-Benzenetricarboxylic acid }\end{array}$ & $\begin{array}{l}\text { GC-MS, DB-5 MS fused-silica } \\
\text { capillary column }\end{array}$ & $\begin{array}{l}\text { Solid phase extraction followed } \\
\text { by microwave-assisted } \\
\text { derivatization: mixture of } \\
\text { LiChrolut EN/Supelclean } \\
\text { ENVI-18 (1:1) sorbents for SPE } \\
\text { and } \\
\text { N,O-bis-(trimethylsilyl)trifluoroac } \\
\text { (BSTFA) with } 1 \% \\
\text { trimethylchlorosilane (TMCS) } \\
\text { for derivatization }\end{array}$ & etamide $^{0.6-15 \mathrm{ng} / \mathrm{L}}$ & {$[36,38,57]$} \\
\hline 23 & $\begin{array}{l}\text { Acetic acid, Propionic acid, Butyric acid, 2-Methylbutyric acid, } \\
\text { Pentanoic acid, Hexanoic acid, Octanoic acid, Nonanoic acid, } \\
\text { Decanoic acid, Dodecanoic acid, Myristic acid, Palmitic acid, } \\
\text { Heptadecanoic acid, Stearic acid, Oleic acid, Linoleic acid, } \\
\text { Benzoic acid, o-Toluic acid, m-Toluic acid, p-Toluic acid, } \\
\text { Phenylacetic acid, Phthalic acid }\end{array}$ & $\begin{array}{l}\text { GC-EI-MS, poly-ethylene glycol } \\
\text { column }\end{array}$ & $\begin{array}{l}\text { SPE: } 80 \mathrm{mg} \text { of LiChrolut } \\
\text { EN/Supelclean ENVI-18 (1:1) }\end{array}$ & Identified and quantified & [44] \\
\hline 24 & $\begin{array}{l}\text { Benzoic acid, 2-methylbenzoic acid, 4-methylbenzoic acid, } \\
\text { 2,4-dimethylbenzoic acid, 4-tert-butylbenzoic acid, } \\
\text { 2-hydroxybenzoic acid, propanoic acid, butyric acid, } \\
\text { 2-ethylhexanoic acid, heptanoic acid, octanoic acid, nonanoic } \\
\text { acid, decanoic acid, 10-undecylenic acid, dodecanoic acid }\end{array}$ & GC-MS, Rxi-624Sil MS & $\begin{array}{l}\text { Ion-pair dispersive } \\
\text { liquid-liquid microextraction } \\
\text { and derivatization method: } \\
\text { chloroform and isopropanol as } \\
\text { disperser solvent and } \\
\text { derivatized by } \\
\text { Tetrabutylammonium } \\
\text { hydrogensulfate }(0.2 \mathrm{M})\end{array}$ & 6.9 to $1120 \mu \mathrm{g} / \mathrm{L}$ & [58] \\
\hline 25 & $\begin{array}{l}\text { Propanoic acid, butanoic acid, heptanoic acid, 2-ethylhexanoic } \\
\text { acid, octanoic acid, benzoic acid, nonanoic acid, } \\
\text { 2-methylbenzoic acid, 2-hydroxybenzoic acid, 4-methylbenzoic } \\
\text { acid, decanoic acid, 2-chlorobenzoic acid (IS), } \\
\text { 2,4-dimethylbenzoic acid, 10-undecylenic acid, } \\
\text { 4-tert-butylbenzoic acid, dodecanoic acid. }\end{array}$ & $\begin{array}{l}\text { GC-MS, Rxi-624Sil MS }(60 \mathrm{~m} \times 0.25 \\
\mathrm{mm} \times 1.40 \mu \mathrm{m})\end{array}$ & $\begin{array}{l}\text { liquid-liquid microextraction: } \\
\text { derivatized by adding } \\
\text { tetrabutylammonium hydrogen } \\
\text { sulfate (TBA-HSO4) }\end{array}$ & $6.9-1120 \mu \mathrm{g} / \mathrm{L}$ & \\
\hline 26 & $\begin{array}{l}\text { Benzoic acid, 2-methylbenzoic acid, 4-methylbenzoic acid, } \\
\text { 2,4-dimethylbenzoic acid, 4-butylbenzoic-tert-butylbenzoic } \\
\text { acid, 2-hydroxybenzoic acid, octanoic acid, nonanoic acid, } \\
\text { decanoic acid, 10-undecylenic acid, dodecanoic acid }\end{array}$ & $\begin{array}{c}\text { GC-MS, HP-5 MS }(30 \mathrm{~m} \times 0.25 \mathrm{~mm} \times \\
0.25 \mu \mathrm{m}) \text { capillary column }\end{array}$ & $\begin{array}{l}\text { liquid-liquid microextraction } \\
\text { and derivatizing: } \\
\text { DES (Choline chloride: } \\
\text { 4-Methyl phenol (1: 2)) } \\
\text { extracting solvent/derivatizing } \\
\text { agent }\end{array}$ & $\begin{array}{c}1.7-8.3 \\
\mu \mathrm{g} / \mathrm{L}\end{array}$ & [59] \\
\hline
\end{tabular}


Table 2. Cont.

\begin{tabular}{|c|c|c|c|c|c|}
\hline & Carboxylic Acids (CAs) & Instrument Type & Sample Preparation & Detection Limit & References \\
\hline 27 & $\begin{array}{l}\text { 3-ketobutanoic acid, 3-methyl-2- } \\
\text { ketobutanoic acid, 9-oxononanoic acid }\end{array}$ & $\begin{array}{c}\text { Fourier transform ion } \\
\text { cyclotron resonance mass } \\
\text { spectrometry (FT-ICR MS), ESI mode }\end{array}$ & D0/D5-GRP reagents & Identified & [8] \\
\hline 28 & $\begin{array}{l}\text { Formic acid acetic acid glycolic acid, oxalic acid, pyruvic acid, } \\
\text { glyoxylic acid, ketobutyric acid and ketomalonic acid }\end{array}$ & ICS-3000 ion chromatograph & Direct injection & $1 \mathrm{mg} / \mathrm{L}$ & [13] \\
\hline 29 & Oxalic and oxamic acids & $\begin{array}{l}\text { HPLC, C18 column } \\
(250 \mathrm{~mm} \times 4.6 \mathrm{~mm})\end{array}$ & Direct injection & Not reported & [40] \\
\hline
\end{tabular}

Identified: Qualitative measurement of carboxylic acids; Quantified: Concentrations of carboxylic acids were measured. 
In addition to GC columns, ion sources and detectors play equally critical roles in method development. Identification and selectivity of CAs are possible using mass spectrometry (MS) but not with flame ionization detectors or electron capture detectors. Similarly, electron ionization (EI), an ion source, is more sensitive than chemical ionization (CI). Therefore, most studies have used MS in combination with EI for identifying or quantifying CAs, as mentioned in Table $2[38,44]$.

\section{Toxicity of CABPs}

There is a paucity of information concerning the health effects of water quality impairment due to CABPs. Instead of determining the toxicity of specific classes of ODBPs, researchers have been more focused on the toxicity of ozonated water [57]. Most of the articles published in the 1970s and 1980s are about the mutagenic activity (MA) of ozonated water and no clear evidence was found of an increase or decrease in MA due to ozonation [21,60]. A study by Kool and Hrube [61] showed increased levels of MA at low ozone doses and no MA at high ozone doses (DBP concentration and type vary according to ozone dose). This variation in MA is highly dependent on the conditions of the treatment process, such as ozone dose, contact time and the stage within the plant at which ozone is applied which in turn effects ODBPs. Currently, no studies have directly reported the potential health effects of CABPs resulting from the ozonation of drinking water. However, a few studies have provided the toxicity data for short-chain CAs (C2-C4) as well as esters, revealing them to be inflammatory or carcinogenic compounds. These data were recorded when CAs were produced as metabolites in human cells during food digestion [60-62]. Moreover, these studies were conducted at concentration of ppm (parts per million), which are 100-1000 times higher than the current detection levels of CABPs in drinking water. Therefore, these results are not comparable with CABPs in drinking water. Model predictions of toxicity of CAs were developed by Moudgal et al. [62] using TOPKAT®/QSTR software. The majority of aliphatic mono- and dicarboxylic acids displayed developmental toxicity. In addition, aliphatic and aromatic dicarboxylic acids were found to be carcinogenic in a female rat sub-model.

ODBPs act as precursors to form chlorination DBPs (HAAs), including aldehydes and CABPs [63]. The most likely pathway leading to the formation of HAAs during ozonation is as follows: NOM $\rightarrow$ (ozonation) $\rightarrow$ aldehydes/CABPs $\rightarrow$ (chlorination) $\rightarrow$ HAAs. Hence, it is possible that ODBPs might act as precursors for HAA formation, especially CABPs. Research conducted by McKnight and Reckhow [63] confirmed the rapid reactivity of pyruvic acid (CABP) with free and combined chlorine and the subsequent formation of chlorinated DBPs. In addition to this formation, the release of these readily biodegradable CABPs in water distribution systems aids microbial regrowth and causes issues with taste and odor in drinking water [64,65]. Studies have shown an increase in the growth of NOX strain (CAs-utilizing isolate) of 15-20 times in ozonated water [65]. Similarly, bacterial regrowth stimulated by oxalic acid (approx. $50 \mu \mathrm{g} \mathrm{eq} / \mathrm{Cl}$ ) indicates the probability of higher microbial growth in the presence of CABPs [64]. In comparison to other DBPs from ozonation, CABPs are poorly removed by filtration processes and enter the water distribution systems [8]. These residual CABPs then react with nitrites and sulfites in drinking water and release toxic gases [66]. Moreover, CAs are reactive to iron, aluminum and steel containers, which may cause the corrosion of water distribution pipes [67]. Therefore, in order to stop CABPs from entering and toxically effecting drinking water, a combination of ozone treatment with filtration or other disinfectants are required. This points to an urgent need for better knowledge about CABP toxicity to characterize the effect of ozonation in water distribution utilities. This information may help the regulatory bodies control CABPs in drinking water. This section may be divided by subheadings. It should provide a concise and precise description of the experimental results, their interpretation as well as the experimental conclusions that can be drawn.

\section{Conclusions}

CABPs are present in higher concentrations than other ozonation DBPs. The formation of CABPs is complex because of numerous factors such as NOM composition and concentration, conditions of ozonation (dose, contact time, etc.) and water treatment processes (filtration processes and secondary 
disinfection). Various sampling approaches for raw water, such as sampling at different water input points (septic installations, wastewater effluents, eutrophic lakes) and at each step of the WTP process may help identify the precursors and mechanisms of CABP formation. CAs have a wide range of molecular weights and polarities associated with them; these properties pose a challenge for developing a single accurate analytical method for analysis. It has been shown that CABPs promote bacterial growth; hence, the occurrence of these highly biodegradable compounds in distribution systems could affect water quality. Moreover, reduced MA due to ozonation and an increase in MA from secondary chlorination disinfection was observed. These observations directly indicate the precursor's activity of ODBPs in forming DBPs from chlorination. This suggests that facilities that apply ozonation should consider implementing efficient treatment processes for the maximum removal of ODBP precursors before applying chlorination as a secondary disinfectant. It is necessary to gather extensive data and evidence of CABP occurrence in drinking water treated by ozonation in order to regulate these CABPs. Similarly, studies should provide transparency about the toxicity of CABPs in water distribution systems, in terms of increased microbial activity and the production of toxic microbial products, as well as the precursor activity of DBPs from chlorination and the consequent potential health effects. It is also essential to evaluate the efficiency of the treatment processes to improve the removal of CABPs or ODBPs. The lack of concrete analytical data and toxicity assessments of CABPs highlights the necessity for further detailed investigations in this field.

Author Contributions: R.P. wrote the original draft; R.P., F.P., S.B., J.-B.S. and M.J.R. contributed directly to project conceptualization and methodology planning; F.P., S.B., J.-B.S. and M.J.R. reviewed and edited the manuscript in detail; S.B. and M.J.R. supervised the project from its beginning and coordinated the funding application. All authors have read and agreed to the published version of the manuscript.

Funding: This research was funded by MITACS, Grant number IT12226. This work is also a part of the research program of the NSERC (Natural Sciences and Engineering Research Council of Canada) Research Chair on Drinking Water of Laval University, Canada.

Acknowledgments: Authors are thankful to Mitacs Accelerate Fellowship program for the scholarship provided to the first author.

Conflicts of Interest: The authors declare no conflict of interest.

\section{References}

1. McGuire, M.J. Eight revolutions in the history of US drinking water disinfection. J. Am. Water Work. Assoc. 2006, 98, 123-149. [CrossRef]

2. Hrudey, S.E. Chlorination disinfection by-products, public health risk tradeoffs and me. Water Res. 2009, 43, 2057-2092. [CrossRef] [PubMed]

3. Nieuwenhuijsen, M.J.; Toledano, M.B.; Eaton, N.E.; Fawell, J.; Elliott, P. Chlorination disinfection byproducts in water and their association with adverse reproductive outcomes: A review. Occup. Environ. Med. 2000, 57, 73-85. [CrossRef]

4. Somani, S.; Ingole, N.; Principal, I.; Ghatkhed, A. Alternative approach to chlorination for disinfection of drinking water an overview. Int. J. Adv. Eng. Res. Stud. 2011, 1, 47-50.

5. Hua, G.; Reckhow, D.A. Comparison of disinfection byproduct formation from chlorine and alternative disinfectants. Water Res. 2007, 41, 1667-1678. [CrossRef] [PubMed]

6. Le Pauloue, J.; Langlais, B. State-of-the-art of ozonation in France. J. Int. Ozone Assoc. 1999. [CrossRef]

7. Loeb, B.L.; Thompson, C.M.; Drago, J.; Takahara, H.; Baig, S. Worldwide ozone capacity for treatment of drinking water and wastewater: A review. Ozone Sci. Eng. 2012, 34, 64-77. [CrossRef]

8. Liu, X.; Liu, R.; Zhu, B.; Ruan, T.; Jiang, G. Characterization of carbonyl disinfection by-products during ozonation, chlorination and chloramination of dissolved organic matters. Environ. Sci. Technol. 2020. [CrossRef]

9. Richardson, S.D.; Thruston, A.D.; Caughran, T.V.; Chen, P.H.; Collette, T.W.; Floyd, T.L.; Schenck, K.M.; Lykins, B.W.; Sun, G.-R.; Majetich, G. Identification of new ozone disinfection byproducts in drinking water. Environ. Sci. Technol. 1999, 33, 3368-3377. [CrossRef] 
10. Park, K.-Y.; Choi, S.-Y.; Lee, S.-H.; Kweon, J.-H.; Song, J.-H. Comparison of formation of disinfection by-products by chlorination and ozonation of wastewater effluents and their toxicity to Daphnia magna. Environ. Pollut. 2016, 215, 314-321. [CrossRef]

11. LoPachin, R.M.; Gavin, T. Molecular mechanisms of aldehyde toxicity: A chemical perspective. Chem. Res. Toxicol. 2014, 27, 1081-1091. [CrossRef] [PubMed]

12. Zhong, X.; Cui, C.; Yu, S. Exploring the pathways of aromatic carboxylic acids in ozone solutions. Rsc Adv. 2017, 7, 34339-34347. [CrossRef]

13. Liu, C.; Tang, X.; Kim, J.; Korshin, G.V. Formation of aldehydes and carboxylic acids in ozonated surface water and wastewater: A clear relationship with fluorescence changes. Chemosphere 2015, 125, 182-190. [CrossRef] [PubMed]

14. Li, C.; Wang, D.; Xu, X.; Wang, Z. Formation of known and unknown disinfection by-products from natural organic matter fractions during chlorination, chloramination and ozonation. Sci. Total Environ. 2017, 587, 177-184. [CrossRef] [PubMed]

15. McDonald, S.; Bishop, A.G.; Prenzler, P.D.; Robards, K. Analytical chemistry of freshwater humic substances. Anal. Chim. Acta 2004, 527, 105-124. [CrossRef]

16. Hammes, F.; Salhi, E.; Köster, O.; Kaiser, H.-P.; Egli, T.; Von Gunten, U. Mechanistic and kinetic evaluation of organic disinfection by-product and assimilable organic carbon (AOC) formation during the ozonation of drinking water. Water Res. 2006, 40, 2275-2286. [CrossRef]

17. Lu, J.; Zhang, T.; Ma, J.; Chen, Z. Evaluation of disinfection by-products formation during chlorination and chloramination of dissolved natural organic matter fractions isolated from a filtered river water. J. Hazard. Mater. 2009, 162, 140-145. [CrossRef]

18. Kusakabe, K.; Aso, S.; Hayashi, J.-I.; Isomura, K.; Morooka, S. Decomposition of humic acid and reduction of trihalomethane formation potential in water by ozone with u.v. irradiation. Water Res. 1990, 24, 781-785. [CrossRef]

19. Krasner, S.; Coffey, B.; Hacker, P.; Hwang, C.; Kuo, C.; Mofidi, A.; Sclimenti, M. The effect of ozonation and biofiltration on NOM. In Proceedings of the Natural Organic Workshop (Influence of Natural Organic Matter Characteristics on Drinking Water Treatment and Quality, La Verne, CA, USA, 18-19 Septembre 1996.

20. Richardson, S.D. Disinfection by-products and other emerging contaminants in drinking water. Trac Trends Anal. Chem. 2003, 22, 666-684. [CrossRef]

21. Miltner, R.J.; Shukairy, H.M.; Summers, R.S. Disinfection by-product formation and control by ozonation and biotreatment. J. Am. Water Work. Assoc. 1992, 84, 53-62. [CrossRef]

22. Xie, Y.; Reckhow, D.A. Formation of ketoacids in ozonated drinking water. J. Int. Ozone Assoc. 1992. [CrossRef]

23. Griffini, O.; Bao, M.; Barbieri, K.; Burrini, D.; Santianni, D.; Pantani, F. Formation and removal of biodegradable ozonation by-products during ozonation-biofiltration treatment: Pilot-scale evaluation. J. Int. Ozone Assoc. 1999. [CrossRef]

24. Can, Z.S.; Gurol, M. Formaldehyde formation during ozonation of drinking water. Ozone Sci. Eng. 2003, 25, 41-51. [CrossRef]

25. Huang, W.-J.; Chen, L.-Y.; Peng, H.-S. Effect of NOM characteristics on brominated organics formation by ozonation. Environ. Int. 2004, 29, 1049-1055. [CrossRef]

26. Huang, W.-J.; Fang, G.-C.; Wang, C.-C. The determination and fate of disinfection by-products from ozonation of polluted raw water. Sci. Total Environ. 2005, 345, 261-272. [CrossRef]

27. Langlais, B.; Reckhow, D.A.; Brink, D.R. Ozone in Water Treatment: Application and Engineering; Routledge: Abingdon, UK, 2019.

28. Kozyatnyk, I.; Świetlik, J.; Raczyk-Stanisławiak, U.; Dabrowska, A.; Klymenko, N.; Nawrocki, J. Influence of oxidation on fulvic acids composition and biodegradability. Chemosphere 2013, 92, 1335-1342. [CrossRef]

29. Glaze, W.H.; Koga, E.C.R.; Cancilla, D. Application of Closed Loop Stripping and XAD Resin Adsorption for the Determination of ozone by-products from natural water. Biohazards Drink. Water Treat. 1988, 1, 201.

30. Porter, P. A Comparison of Ozonation Systems with Respect to Disinfection by-Product Formation and Microbial Inactivation; National Library of Canada = Bibliothèque nationale du Canada: Ottawa, ON, Canada, 2000.

31. Peldszus, S.; Huck, P.M.; Andrews, S.A. Determination of short-chain aliphathic, oxo-and hydroxy-acids in drinking water at low microgram per liter concentrations. J. Chromatogr. A 1996, 723, 27-34. [CrossRef] 
32. Kuo, C.-Y. Improved application of ion chromatographic determination of carboxylic acids in ozonated drinking water. J. Chromatogr. A 1998, 804, 265-272. [CrossRef]

33. Gagnon, G.A.; Booth, S.D.; Peldszus, S.; Mutti, D.; Smith, F.; Huck, P.M. Carboxylic acids: Formation and removal in full-scale plants. J. Am. Water Work. Assoc. 1997, 89, 88-97. [CrossRef]

34. Richardson, S.D.; Caughran, T.V.; Poiger, T.; Guo, Y.; Crumley, F.G. Application of DNPH derivatization with LC/MS to the identification of polar carbonyl disinfection byproducts in drinking water. Ozone Sci. Eng. 2000, 22, 653-675. [CrossRef]

35. Nawrocki, J.; Świetlik, J.; Raczyk-Stanisławiak, U.; Dąbrowska, A.; Biłozor, S.; Ilecki, W. Influence of ozonation conditions on aldehyde and carboxylic acid formation. Ozone Sci. Eng. 2003, 25, 53-62. [CrossRef]

36. Jurado-Sánchez, B.; Ballesteros, E.; Gallego, M. Occurrence of carboxylic acids in different steps of two drinking-water treatment plants using different disinfectants. Water Res. 2014, 51, 186-197. [CrossRef]

37. Richardson, S.; Thruston, A.; Caughran, T.; Chen, P.; Collette, T.; Schenck, K.; Lykins, B.; Rav-Acha, C.; Glezer, V. Identification of new drinking water disinfection by-products from ozone, chlorine dioxide, chloramine and chlorine. Water Air Soil Pollut. 2000, 123, 95-102. [CrossRef]

38. Jurado-Sánchez, B.; Ballesteros, E.; Gallego, M. Determination of carboxylic acids in water by gas chromatography-mass spectrometry after continuous extraction and derivatisation. Talanta 2012, 93, 224-232. [CrossRef] [PubMed]

39. Zhong, X.; Cui, C.; Yu, S. Seasonal evaluation of disinfection by-products throughout two full-scale drinking water treatment plants. Chemosphere 2017, 179, 290-297. [CrossRef]

40. Faria, P.C.C.; Órfão, J.J.M.; Pereira, M.F.R. Activated carbon catalytic ozonation of oxamic and oxalic acids. Appl. Catal. B Environ. 2008, 79, 237-243. [CrossRef]

41. Kuo, C.-Y.; Krasner, S.W.; Davis, M.K.; Minera, R.A.; Amy, G.L. Water Disinfection and Natural Organic Matter: Characterization and Control (ACS Symposium Series, No. 649); American Chemical Society: Washington, DC, USA, 1996; p. 350.

42. Beale, R.; Liss, P.; Nightingale, P. First oceanic measurements of ethanol and propanol. Geophys. Res. Lett. 2010, 37. [CrossRef]

43. Kuo, P.P.; Chian, E.S.; Chang, B.J. Identification of end products resulting from ozonation and chlorination of organic compounds commonly found in water. Environ. Sci. Technol. 1977, 11, 1177-1181. [CrossRef]

44. Jurado-Sánchez, B.; Ballesteros, E.; Gallego, M. Determination of carboxylic acids in water by gas chromatography using several detectors after flow preconcentration. J. Chromatogr. A 2010, 1217, 7440-7447. [CrossRef]

45. Rompa, M.; Kremer, E.; Zygmunt, B. Derivatisation in gas chromatographic determination of acidic herbicides in aqueous environmental samples. Anal. Bioanal. Chem. 2003, 377, 590-599. [CrossRef] [PubMed]

46. Pan, L.; Adams, M.; Pawliszyn, J. Determination of fatty acids using solid phase microextraction. Anal. Chem. 1995, 67, 4396-4403. [CrossRef]

47. Pan, L.; Pawliszyn, J. Derivatization/solid-phase microextraction: New approach to polar analytes. Anal. Chem. 1997, 69, 196-205. [CrossRef]

48. Wert, E.C.; Rosario-Ortiz, F.L.; Drury, D.D.; Snyder, S.A. Formation of oxidation byproducts from ozonation of wastewater. Water Res. 2007, 41, 1481-1490. [CrossRef]

49. Glaze, W.H.; Koga, M.; Cancilla, D.; Wang, K.; McGuire, M.J.; Liang, S.; Davis, M.K.; Tate, C.H.; Aieta, E.M. Evaluation of ozonation by-products from two California surface waters. J. Am. Water Work. Assoc. 1989, 81, 66-73. [CrossRef]

50. Richardson, S.D.; Thruston, A.D.; Collette, T.W.; Patterson, K.S.; Lykins, B.W.; Majetich, G.; Zhang, Y. Multispectral identification of chlorine dioxide disinfection byproducts in drinking water. Environ. Sci. Technol. 1994, 28, 592-599. [CrossRef]

51. Peldszus, S.; Huck, P.M.; Andrews, S.A. Quantitative determination of oxalate and other organic acids in drinking water at low $\mu \mathrm{g} / \mathrm{l}$ concentrations. J. Chromatogr. A 1998, 793, 198-203. [CrossRef]

52. Yo, S.-P. Analysis of volatile fatty acids in wastewater collected from a pig farm by a solid phase microextraction method. Chemosphere 1999, 38, 823-834. [CrossRef]

53. Cruwys, J.; Dinsdale, R.; Hawkes, F.; Hawkes, D. Development of a static headspace gas chromatographic procedure for the routine analysis of volatile fatty acids in wastewaters. J. Chromatogr. A 2002, 945, 195-209. [CrossRef] 
54. Abalos, M.; Bayona, J. Application of gas chromatography coupled to chemical ionisation mass spectrometry following headspace solid-phase microextraction for the determination of free volatile fatty acids in aqueous samples. J. Chromatogr. A 2000, 891, 287-294. [CrossRef]

55. Abalos, M.; Bayona, J.; Pawliszyn, J. Development of a headspace solid-phase microextraction procedure for the determination of free volatile fatty acids in waste waters. J. Chromatogr. A 2000, 873, 107-115. [CrossRef]

56. Ohta, K.; Ohashi, M.; Jin, J.-Y.; Takeuchi, T.; Fujimoto, C.; Choi, S.-H.; Ryoo, J.-J.; Lee, K.-P. Separation of aliphatic carboxylic acids and benzenecarboxylic acids by ion-exclusion chromatography with various cation-exchange resin columns and sulfuric acid as eluent. J. Chromatogr. A 2003, 997, 117-125. [CrossRef]

57. Li, C.; Wang, D.; Li, N.; Luo, Q.; Xu, X.; Wang, Z. Identifying unknown by-products in drinking water using comprehensive two-dimensional gas chromatography-quadrupole mass spectrometry and in silico toxicity assessment. Chemosphere 2016, 163, 535-543. [CrossRef] [PubMed]

58. Makoś, P.; Fernandes, A.; Boczkaj, G. Method for the determination of carboxylic acids in industrial effluents using dispersive liquid-liquid microextraction with injection port derivatization gas chromatography-mass spectrometry. J. Chromatogr. A 2017, 1517, 26-34. [CrossRef]

59. Makoś, P.; Fernandes, A.; Przyjazny, A.; Boczkaj, G. Sample preparation procedure using extraction and derivatization of carboxylic acids from aqueous samples by means of deep eutectic solvents for gas chromatographic-mass spectrometric analysis. J. Chromatogr. A 2018, 1555, 10-19. [CrossRef]

60. Zoeteman, B.; Hrubec, J.; De Greef, E.; Kool, H. Mutagenic activity associated with by-products of drinking water disinfection by chlorine, chlorine dioxide, ozone and UV-irradiation. Environ. Health Perspect. 1982, 46, 197-205. [CrossRef]

61. Kool, H.; Hrubec, J. The Influence of an Ozone, Chlorine and Chlorine Dioxide Treatment on Mutagentic Activity in (Drinking) Water; Taylor \& Francis: Abingdon, UK, 1986.

62. Moudgal, C.J.; Lipscomb, J.C.; Bruce, R.M. Potential health effects of drinking water disinfection by-products using quantitative structure toxicity relationship. Toxicology 2000, 147, 109-131. [CrossRef]

63. McKnight, A.; Reckhow, D.A. Reactions of ozonation byproducts with chlorine and chloramines. In Proceedings of the Conference proceedings, AWWA Annual Conference, Vancouver, BC, Canada, 18-22 June 1992.

64. Chu, C.; Lu, C. Effects of oxalic acid on the regrowth of heterotrophic bacteria in the distributed drinking water. Chemosphere 2004, 57, 531-539. [CrossRef]

65. Van der Kooij, D.; Hijnen, W. Substrate utilization by an oxalate-consuming Spirillum species in relation to its growth in ozonated water. Appl. Environ. Microbiol. 1984, 47, 551-559. [CrossRef]

66. CAMEO Chemicals. Available online: https://cameochemicals.noaa.gov/react/3 (accessed on 15 January 2019).

67. Sandvik. Available online: https://www.materials.sandvik/en/materials-center/corrosion-tables/2019 (accessed on 15 January 2019). 